Louisiana State University

LSU Digital Commons

Faculty Publications

Department of Chemistry

6-15-2018

\title{
Tetrafluorobenzo-Fused BODIPY: A Platform for Regioselective Synthesis of BODIPY Dye Derivatives
}

\author{
Andrea Savoldelli \\ Università degli Studi di Roma Tor Vergata \\ Qianli Meng \\ Louisiana State University \\ Roberto Paolesse \\ Università degli Studi di Roma Tor Vergata \\ Frank R. Fronczek \\ Louisiana State University \\ Kevin M. Smith \\ Louisiana State University
}

See next page for additional authors

Follow this and additional works at: https://digitalcommons.Isu.edu/chemistry_pubs

\section{Recommended Citation}

Savoldelli, A., Meng, Q., Paolesse, R., Fronczek, F., Smith, K., \& Vicente, M. (2018). Tetrafluorobenzo-Fused BODIPY: A Platform for Regioselective Synthesis of BODIPY Dye Derivatives. Journal of Organic Chemistry, 83 (12), 6498-6507. https://doi.org/10.1021/acs.joc.8b00789

This Article is brought to you for free and open access by the Department of Chemistry at LSU Digital Commons. It has been accepted for inclusion in Faculty Publications by an authorized administrator of LSU Digital Commons.

For more information, please contact ir@lsu.edu. 


\section{Authors}

Andrea Savoldelli, Qianli Meng, Roberto Paolesse, Frank R. Fronczek, Kevin M. Smith, and M. Graça H. Vicente 
Published in final edited form as:

J Org Chem. 2018 June 15; 83(12): 6498-6507. doi:10.1021/acs.joc.8b00789.

\title{
Tetrafluorobenzo-Fused BODIPY: A Platform for Regioselective Synthesis of BODIPY Dye Derivatives
}

\author{
Andrea Savoldelli†, Qianli Meng ${ }^{\ddagger}$, Roberto Paolesse ${ }^{\dagger}$, Frank R. Fronczek ${ }^{\ddagger}$, Kevin M. Smith $^{\ddagger}$, \\ M. Graçca H. Vicente ${ }^{*}, \ddagger$ \\ †Dipartimento di Scienze e Tecnologie Chimiche, University of Rome Tor Vergata, Via della \\ Ricerca Scientifica 1, 00133 Rome, Italy \\ ‡Department of Chemistry, Louisiana State University, Baton Rouge, Louisiana 70803, United \\ States
}

\begin{abstract}
A novel route for the synthesis of unsymmetrical benzo-fused BODIPYs is reported using 4,5,6,7tetrafluoroisoindole as a precursor. The reactivity of the 3,5-dibromo tetrafluorobenzo-fused BODIPY was investigated under nucleophilic substitution and $\mathrm{Pd}(0)$-catalyzed cross-coupling reaction conditions. In addition to the 3,5-bromines, one $a$-fluoro group on the benzo-fused ring can also be functionalized, and an unusual homocoupling with formation of a bisBODIPY was observed. This new class of fluorinated BODIPYs could find various applications in medicine and materials.
\end{abstract}

\section{Graphical Abstract}
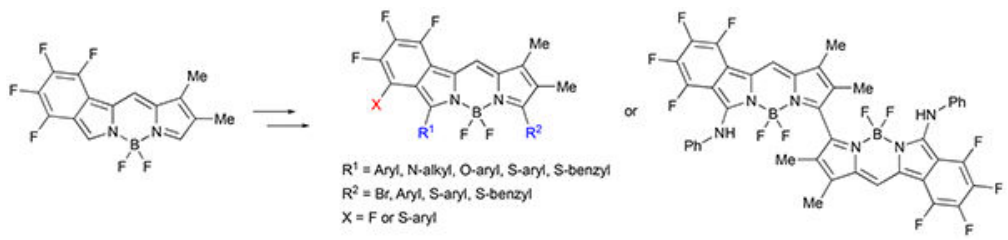

\section{INTRODUCTION}

4,4-Difluoro-4-bora-3a,4a-diaza-s-indacene dyes, usually abbreviated as BODIPYs, have been extensively studied in recent years. These small molecules offer unique properties, including high photostability, high molar absorption coefficients, and high fluorescence quantum yields, ${ }^{1}$ which have supported their exploitation as imaging probes, ${ }^{2}$ fluorescent organic devices, ${ }^{3}$ chemical sensors, ${ }^{4}$ and as photosensitizers. ${ }^{5}$ The properties of this class of molecule can be easily and finely tuned with the insertion of various substituents. One of the

\footnotetext{
*Corresponding Author: vicente@1su.edu.

Supporting Information

The Supporting Information is available free of charge on the ACS Publications website at DOI: 10.1021/acs.joc.8b00789.

X-ray data for BODIPYs 1, 4d, 4e, 6, and 7 (CIF) Additional UV-vis and emission spectra; ${ }^{1} \mathrm{H},{ }^{13} \mathrm{C},{ }^{19} \mathrm{~F}$, and ${ }^{11} \mathrm{~B}$ NMR and $2 \mathrm{D}$ NMR spectra (PDF)

The authors declare no competing financial interest.
} 
most exploited routes in BODIPY functionalization relies on the synthesis of a corehalogenated precursor (chlorinated, ${ }^{6}$ brominated ${ }^{7}$ or iodinated ${ }^{8}$ BODIPY), which can be readily synthesized with high regioselectivity and represents a versatile precursor in nucleophilic substitution reactions using $\mathrm{N}-, \mathrm{S}-, \mathrm{O}-$, and C-centered nucleophiles ${ }^{9}$ and in $\operatorname{Pd}(0)$-catalyzed cross-coupling reactions. ${ }^{10}$ Many BODIPY applications require the synthesis of long-wavelength absorbing and emitting species (ca. 600-800 nm), although most BODIPYs reported to date emit at wavelengths lower than $600 \mathrm{~nm}$. Among the possible solutions to this issue, BODIPYs with an aromatic ring fused at the $\beta, \beta^{\prime}$-pyrrolic positions are particularly interesting, since they generally provide highly planar BODIPY platforms featuring largely red-shifted absorptions and emissions, as well as enhanced hydrophobicity and cell permeability. ${ }^{11,12}$ Recently, much research has been directed at the discovery of new synthetic pathways to introduce benzo-fused rings in the BODIPY scaffold, mainly using 4,5,6,7-tetrahydroisoindole, ${ }^{8 \mathrm{~d}, 12}$ norbornane-derived pyrroles, ${ }^{13}$ or 3halogeno-1-formyliso-indoles ${ }^{14}$ as reagents (Scheme 1), where only the last example represents a route not requiring harsh conditions.

Exploitation of 1,2,3-unsubstituted isoindoles is usually prevented by their high instability, both in solution and in the solid state. A special case is represented by 4,5,6,7tetrafluoroisoindole, which has already been demonstrated to be stable in the solid state because of its crystal packing. ${ }^{15}$ For this reason, we decided to explore the preparation of asymmetrical benzo-fused BODIPYs using 4,5,6,7-tetrafluoroisoindole as the starting material. We report here a synthetic route to unsymmetrically substituted BODIPY 1 and the investigation of the reactivity of this novel dye toward functionalization by $\operatorname{Pd}(0)$-catalyzed cross-coupling and nucleophilic substitution reactions, leading to a variety of regioselectively functionalized products. This methodology could be applied in the preparation of fluorinated BODIPYs with various applications, including in ${ }^{19} \mathrm{~F} \mathrm{NMR}$ and near-IR imaging. ${ }^{16}$

\section{RESULTS AND DISCUSSION}

\section{Synthesis.}

4,5,6,7-Tetrafluoroisoindole has already been reported in the literature ${ }^{15}$ as a stable intermediate in the synthesis of fluorinated benzoporphyrins. We decided to investigate the reactivity of this tetrafluoroisoindole in the presence of 2-formyl-3,4-dimethylpyrrole under typical reaction conditions for BODIPY syntheses, ${ }^{17}$ using $\mathrm{POCl}_{3}$ as the acid catalyst and $\mathrm{BF}_{3} \cdot \mathrm{Et}_{2} \mathrm{O}$ as the boron source, obtaining 1 in $60 \%$ yield (Scheme 2). Slow diffusion of hexane into a dichloromethane solution afforded crystals suitable for $\mathrm{X}$-ray analysis, thus allowing the unambiguous characterization of this compound (Figure 1). The $\mathrm{C}_{9} \mathrm{~N}_{2} \mathrm{~B}$ BODIPY core of 1 is slightly nonplanar, with a mean deviation $0.043 \AA$, and it is bowed, with the two five-membered rings tipped on the same side of the best plane. Its central sixmembered $\mathrm{C}_{3} \mathrm{~N}_{2} \mathrm{~B}$ ring has a slight envelope conformation, with the $\mathrm{B}$ atom lying $0.087 \AA$ out of the plane of the other five atoms. One F coordinated to B is thus farther out of the plane than the other, by 1.278 and $0.969 \AA$. The $\mathrm{C}-\mathrm{C}(\mathrm{Me})$ distances are 1.4946(14) and 1.4915(13) $\AA$, and the C-F distances are in the range 1.3390(11)-1.3408(11) $\AA$. 
Isoindole BODIPY 1 was then brominated at the 3,5-positions, using liquid bromine in dichloromethane, ${ }^{7}$ to give 2 in nearly quantitative yield (Scheme 2). The low solubility of 2 in all of the common organic solvents prevented both its chromatographic separation and NMR characterization; how-ever, recrystallization of the crude reaction product afforded 2 in high purity, as evidenced by TLC analysis, UV-vis spectroscopy, and confirmed by ESIHRMS. The reactivity of BODIPY 2 was investigated under nucleophilic substitution and $\operatorname{Pd}(0)$-catalyzed cross-coupling Suzuki and Stille reactions, to generate various functionalized fluorinated BODIPYs, as described below.

\section{Nucleophilic Substitution Reactions.}

We investigated the reactivity of 2 toward nucleophilic substitution processes with C-, N-, O-, or S-centered nucleophiles, as shown in Scheme 3. Nucleophilic substitutions on 3,5halogenated BODIPYs have been previously reported in the literature, ${ }^{9}$ and these reactions generally produce the target 3,5-functionalized products in high yields. In our case, we selected THF or toluene as solvents because of the complete insolubility of isoindole BODIPY 2 in acetonitrile, which is usually used in nucleophilic substitution reactions. Although 2 is only slightly soluble in THF and toluene, all of the generated products were soluble in these solvents, which facilitated their isolation and characterization.

Sulfur-centered nucleophiles were demonstrated to be highly reactive, affording the corresponding 3,5-disubstituted products at room temperature in short reaction times. For example, when benzylmercaptan ( 3 equiv) was used in a short reaction time (15 min), BODIPY $4 \mathrm{e}$ was isolated in $40 \%$ yield (Scheme 3 ). In the case of an aromatic thiol, such as 4-methylbenze-nethiol, the reactivity is even higher. The disubstituted BODIPY $4 \mathrm{~d}$ was obtained in 3 min using 2 equiv of thiol reagent in THF at room temperature. For both of the disubstituted compounds $4 \mathrm{~d}$ and $4 \mathrm{e}$, crystals suitable for X-ray analysis were obtained from slow diffusion of hexane into a dichloromethane solution (Figure 1), allowing the unambiguous characterization of these compounds. The $\mathrm{C}_{9} \mathrm{~N}_{2} \mathrm{~B}$ BODIPY core of $4 \mathrm{~d}$ is nearly planar, with a mean deviation $0.023 \AA$. The phenyl rings of the 4-methylbenzenethiol substituents form dihedral angles of $87.4^{\circ}$ and $68.1^{\circ}$ with the core plane. There are two independent molecules in the asymmetric unit of $4 \mathrm{e}$, and each has the $\mathrm{S}-\mathrm{CH}_{2}-\mathrm{Ph}$ nearest the fluorinated phenyl ring disordered into two conformations. In one of the two molecules, the $\mathrm{C}_{9} \mathrm{~N}_{2} \mathrm{~B}$ BODIPY core is very nearly planar, with a mean deviation $0.014 \AA$. In the other, the $\mathrm{C}_{9} \mathrm{~N}_{2} \mathrm{~B}$ core has a slightly bowed conformation, with a mean deviation of $0.068 \AA$, the $\mathrm{B}$ atom having the largest out-of-plane deviation of $0.160 \AA$.

The use of 3 equiv of 4-methylbenzenethiol at room temperature in THF led to the isolation of the unexpected trisubstituted compound $5 \mathrm{~d}$ in $75 \%$ yield, as confirmed by ${ }^{19} \mathrm{~F}$ NMR spectroscopy (see the Supporting Information) and ${ }^{1} \mathrm{H}-{ }^{19} \mathrm{~F}$ HOESY (see Figure 5), where one of the fluorine atoms on the benzo-fused ring was also substituted (Scheme 3). Interestingly, only one trisubstituted regioisomer was obtained, indicating a higher reactivity for the $a$ rather than the $\beta$ fluoro group, as observed in fluorinated phthalocyanines. ${ }^{18}$ Increasing the number of equivalents of 4-methylbenzenethiol did not result in additional substitution reactions of the remaining fluorine atoms. 
High regioselectivity was also observed in the case of carbon-, oxygen-, and nitrogencentered nucleophiles, where the 3-bromo adjacent to the benzo-fused ring showed the highest reactivity. Using 5 or 10 equiv of 3-ethyl-2,4-dimethylpyrrole as the nucleophile, at $80{ }^{\circ} \mathrm{C}$ in toluene, produced monosub-stituted $3 \mathrm{a}$ or disubstituted 4 a BODIPYs respectively, in $60-77 \%$ yields (Scheme 3). The ${ }^{19}$ F NMR spectra of these compounds (see the Supporting Information) showed two different multiplet signals for the two fluorines linked to the boron atom, confirming a hydrogen bonding interaction between the fluorine atoms linked to the boron and the $\mathrm{N}$-hydrogen of the peripheral pyrrole, as previously observed. 9d,14d Moreover, in the ${ }^{1} \mathrm{H}$ NMR spectra of both $3 \mathrm{a}$ and $4 \mathrm{a}$ (see the Supporting Information and Figure 2), one of the methyl groups corresponding to the pyrrolic substituent shows a signal that is clearly split into two singlets, and a similar split is also observed in the case of one of the two pyrrolic N-hydrogens. Therefore, we hypothesize that the first pyrrole unit introduced at the 3-position can also have a hydrogen bonding interaction with the $a$ fluorine group of the adjacent benzo-fused ring, in both cases forming a seven-membered ring structure; the two structures coexist in solution in the time scale of the ${ }^{1} \mathrm{H}$ NMR experiment, causing the splitting of the signals as shown in Figure 2.

Even higher regioselectivity was observed in the case of oxygen- and nitrogen-centered nucleophiles. Using an excess of 4-methoxyphenol as the oxygen nucleophile, in the presence of $\mathrm{K}_{2} \mathrm{CO}_{3}$ at room temperature, only the monosubstituted BODIPY 3c was produced (Scheme 3). A similar result was observed when piperidine was used as the nucleophile, producing BODIPY $3 \mathrm{~b}$ in $93 \%$ yield. Unlike previous reports, ${ }^{9 \mathrm{a}}$ attempts to push the reaction to the formation of the disubstituted products failed, suggesting a peculiar deactivation in the reactivity of the second bromine atom. Even though the formation of $3 b$ was readily accomplished after $15 \mathrm{~min}$ at room temperature, formation of the disubstituted product was not detected, even upon increasing the reaction time, the amount of nucleophile, and the reaction temperature.

Furthermore, an unexpected result occurred when aniline was used as the nitrogen nucleophile, in THF at room temperature. After $1 \mathrm{~h}$, complete consumption of the starting material was observed, along with formation of bisBODIPY 6 in $65 \%$ yield (Scheme 3). No monomeric products were obtained under these conditions. We hypothesize that, upon formation of the monosubstituted product at the 3-position, the remaining bromine group, which is deactivated toward nucleophilic substitution, undergoes an unusual homocoupling reaction to produce 6 . Previous literature reports ${ }^{19}$ have used aniline as a reducing agent in the synthesis of metal nanoparticles in water solutions. This peculiar reactivity of aniline in our homocoupling reaction is still under investigation. Crystals of BODIPY 6 suitable for Xray analysis were obtained from slow diffusion of hexane into a dichloromethane solution, allowing the unambiguous characterization of this compound, as shown in Figure 3. The dimeric molecule lies on a crystallographic two-fold axis, so the two BODIPYs are identical by symmetry. The torsion angle about the central $\mathrm{C}-\mathrm{C}$ bond is $-94.9(2)^{\circ}$; thus the two BODIPY cores are approximately orthogonal, forming a dihedral angle of $86.8^{\circ}$. Each $\mathrm{C}_{9} \mathrm{~N}_{2} \mathrm{~B}$ BODIPY core has the same slightly bowed conformation seen in 1, with a mean deviation of $0.057 \AA$. The envelope distortion of the central $\mathrm{C}_{3} \mathrm{~N}_{2} \mathrm{~B}$ ring is more pronounced than in 1, with the B atom lying $0.190 \AA$ out of the plane of the other five atoms and the $\mathrm{F}$ atoms 0.730 and $1.457 \AA$ out of plane. This greater distortion may be explained by an 
intramolecular hydrogen bond from the aniline substituent to one of the $\mathrm{F}$ atoms on B, with $\mathrm{N} \cdots \mathrm{F}$ distance 2.8514(19) $\AA$ and angle about $\mathrm{H} 136.3(18)^{\circ}$.

\section{D NMR Identification of Products.}

For all of the monosubstituted BODIPYs 3a, 3b, and 3c, multiple 2D NMR experiments were performed in order to verify the position of the substituent. Figure 4 shows the HMBC and NOESY spectra obtained for $3 b$ (corresponding spectra for $3 a$ and $3 c$ can be found in the Supporting Information). HMQC and $\mathrm{HMBC}$ experiments were performed; the first procedure is selective for directly bonded ${ }^{1} \mathrm{H}-{ }^{13} \mathrm{C}$ atoms, while the latter detects long-range ${ }^{1} \mathrm{H}-{ }^{13} \mathrm{C}$ coupling (up to 4 bond distance coupling). In the HMBC spectrum of $3 \mathrm{~b}$, the ${ }^{1} \mathrm{H}$ signal at $3.82 \mathrm{ppm}$, corresponding to the $2,6-\mathrm{CH}_{2}$ group of piperidine, correlates to four different carbon atoms (Figure 4). The peaks at 23.27, 26.18, and $53.76 \mathrm{ppm}$ proved to be the piperidine carbon atom signals from the HMQC experiment; therefore, the signal at 157.44 ppm belongs to the carbon atom at either the 3- or the 5-position of the BODIPY. Since neither of the two methyl groups of $3 \mathrm{~b}$ is coupled to that specific carbon atom, it has to be the one at the $\mathrm{C}-3$ position, and similarly for the pyridine substituent. Moreover, from the NOESY experiment (Figure 4), while the hydrogen atoms for one of the methyl groups (2.17 ppm) show a through-space interaction with the hydrogen atom at the 8-position, no correlation is detected between the methyl groups and the hydrogen atoms of piperidine.

A different approach was used for the structural characterization of trisubstituted compound 5d. In order to establish the position of the thiol substituent on the benzo-fused ring, ${ }^{1} \mathrm{H}-{ }^{19} \mathrm{~F}$ HOESY experiments were performed. These showed a cross-peak between the BODIPY hydrogen at the 8-position and the fluorine atom labeled as F4 in Figure 5. On the other hand, in the monodimensional ${ }^{19} \mathrm{~F}$ NMR spectrum of BODIPY 5d, fluorines F2, F3, and F4 produced three distinctive signals, two doublets and one triplet, all with the same $J$ value. This indicates that the remaining fluorine atom is in the vicinal position, and therefore, the thiol substituent regioselectively displaced the F1 atom.

\section{Pd(0)-Catalyzed Cross-Coupling Reactions.}

The reactivity of BODIPY 2 was also investigated under $\mathrm{Pd}(0)$-catalyzed cross-coupling reactions. Good yields of the targeted bifunctionalized products were obtained using Suzuki and Stille cross-couplings (Scheme 4), while significant decomposition was observed in the case of Sonogashira and Heck coupling reactions, probably due to the harsher reaction conditions and the larger amount of base required in the latter reactions. $\mathrm{Pd}\left(\mathrm{PPh}_{3}\right)_{2} \mathrm{Cl}_{2}$ was used as the catalyst for both Stille and Suzuki coupling reactions, since $\mathrm{Pd}\left(\mathrm{PPh}_{3}\right)_{4}$ was observed to be less effective, and $\mathrm{K}_{2} \mathrm{CO}_{3}$ was used as the base in the Suzuki coupling reactions. The 3,5-dicoupled products $\mathbf{7 , 8}$, and $\mathbf{9}$ were obtained in moderate yields upon refluxing in toluene, or in 1:1 toluene/THF for up to $4 \mathrm{~h}$. BODIPY 7 was obtained from a Suzuki coupling reaction, and crystals suitable for X-ray analysis were obtained from slow diffusion of hexane into a dichloromethane solution, allowing for the unambiguous characterization of this compound (Figure 6). The BODIPY cores of three independent molecules in the asymmetric unit all have similar slightly bowed conformations. Mean 12atom deviations for the three are $0.054,0.080$, and $0.088 \AA$, and in all three cases, the $\mathrm{B}$ atom has the largest deviation, by $0.153,0.192$, and $0.182 \AA$, respectively. Dihedral angles 
between the 12-atom BODIPY core and the phenyl groups at the 3,5-positions in 7 range from $60.7^{\circ}$ to $68.3^{\circ}$ over the three independent molecules, with an average value of $65.2^{\circ}$.

BODIPYs $\mathbf{8}$ and $\mathbf{9}$ were obtained from both Suzuki and Stille coupling reactions in moderate yields, with better results in the case of the Stille cross-coupling reactions due to the shorter reaction times (typically $1 \mathrm{~h}$ ) and no base requirement, ${ }^{6 \mathrm{~d}}$ which minimized BODIPY decomposition.

\section{Spectroscopic Characterization.}

The spectroscopic properties of the fluorinated BODIPYs in THF are summarized in Table 1. Figure 7 shows the normalized UV-vis absorption and emission spectra of selected BODIPYs (additional spectra can be found in the Supporting Information). For all of the BODIPYs, the absorption spectra showed typical BODIPY features, with a strong band between $560 \mathrm{~nm}$ for 1 and $690 \mathrm{~nm}$ for $4 \mathrm{a}$, corresponding to the $\mathrm{S} 0 \rightarrow \mathrm{S} 1$ transition, and a blue-shifted vibrational transition as a shoulder. Only dimer 6 showed different behavior, similar to that previously reported for bisBODIPYs,${ }^{20}$ with two distinctive absorption bands with similar molar extinction coefficients (see the Supporting Information). The two main differences observed between 6 and the previously reported bisBODIPYs are (1) lower molar absorption coefficient and (2) low fluorescence quantum yield observed for 6 . Both of these differences are due to the presence of the aniline substituents at the pyrrolic $a$ positions in 6 . Aniline monosubstituted monomeric BODIPYs ${ }^{9 \mathrm{a}, 21}$ are known to display lower molar absorption coefficients and lower fluorescence quantum yields compared with their 3-halogenated precursors. Moreover, the fluorescence quantum yields of bisBODIPY dimers are usually lower than the corresponding monomeric species, due to the enhancement of the intersystem crossing efficiency as a result of an exciton-split excited state. ${ }^{20}$

Both monosubstituted compounds $3 \mathrm{~b}$ and $3 \mathrm{c}$ showed very high fluorescence quantum yields despite the presence of bromine, almost similar to the precursor BODIPY 1, with a larger Stokes shift for $\mathbf{3 b}$. In these cases, the remaining bromine group at the pyrrolic $\boldsymbol{a}$-position does not significantly affect the emission properties, as is normally observed when bromine occupies a pyrrolic $\beta$-position due to the heavy halogen atom effect, which facilitates intersystem crossing ${ }^{22}$. This result is consistent with previous literature, which reports low fluorescence quantum yields in the case of poly-brominated compounds. ${ }^{7 \mathrm{~d}, 23}$ BODIPY $3 \mathrm{~b}$ also displayed a lower molar absorption coefficient compared with the other monomeric BODIPYs, due to the $\mathrm{N}$-substitution at the $a$-pyrrolic position, in agreement with previous observations. ${ }^{9 \mathrm{a}, 21}$ Furthermore, no fluorescence emission was detected for $3 \mathrm{a}$ and $4 \mathrm{a}$ in THF, as previously reported for 3-pyrrole substituted isoindole BODIPYs, due to the solvent polarity. ${ }^{14}$ However, in nonpolar solvents such as hexane and toluene, these types of compounds typically show high fluorescence quantum yields. In addition, $4 \mathbf{a}$ showed the most red-shifted absorption spectrum, $130 \mathrm{~nm}$ shift compared with starting BODIPY 1, due to the significant enhancement of the $\pi$-electron delocalization system, in part as a result of the pyrrolic $\mathrm{NH}^{\cdots} \mathrm{F}$ hydrogen bond. BODIPY 9 bearing 3,5-furyl groups also showed a large red-shifted absorption spectrum, by $109 \mathrm{~nm}$ relative to $\mathbf{1}$, as previously observed. ${ }^{\mathrm{ee}}$ On the other hand, BODIPYs 7 and 8 showed only moderately red-shifted absorption and emission spectra relative to 1 , in the order of $35 \mathrm{~nm}$, due to the larger dihedral angles (ca. $65^{\circ}$ ) 
between the 3,5-phenyl rings and the BODIPY core, as seen in Figure 6. Both BODIPYs 7 and $\mathbf{8}$ show very high fluorescence quantum yields of nearly 1 , while $\mathbf{9}$ showed a drastic decrease in the quantum yield, due to the greater freedom of rotation of the furyl group compared with phenyl, leading to increased energy lost to nonradiative decay to the ground state.

The fluorinated BODIPYs substituted with oxygen or nitrogen atoms at the 3-position, such as $\mathbf{3 b}$ and $\mathbf{3 c}$, showed slight red-shifted absorptions and emissions relative to $\mathbf{1}(2-13 \mathrm{~m})$, increased Stokes shifts, particularly in the case of $\mathbf{3 b}$, and slightly decreased quantum yields. Among the 3,5-disubstituted BODIPYs with sulfur atoms, 4d bearing the aromatic thiol substituent displayed a larger red-shifted absorption and emission spectra relative to $4 \mathbf{e}$ substituted with benzylthiol, along with decreased fluorescence quantum yield. In addition, replacement of one $a$-fluoro atom on the benzo-fused ring with another 4-methylphenylthio group further red-shifted the absorption and emission of $\mathbf{5 d}$ compared with the disubstituted 4d, by 17 and $19 \mathrm{~nm}$, respectively.

\section{CONCLUSION}

A novel fluorinated and 3,5-brominated benzo-fused BODIPY 2 was synthesized from a 4,5,6,7-tetrafluoroisoindole precursor, followed by bromination in high yields. The functionalization of $\mathbf{2}$ under nucleophilic substitution reactions using C-, N-, O-, or Scentered nucleophiles led to the preparation of mono-, di-, or trisubstituted products, and a bisBODIPY. The most reactive position was the bromo group on the isoindole unit, followed by the bromo group on the pyrrole ring, followed by an $a$-fluoro group on the isoindole. All the products were obtained under mild conditions, and their structures were confirmed by 1D and 2D NMR spectroscopy, and in the case of $\mathbf{4 d}$ and $\mathbf{4 e}$, by X-ray crystallography. Isoindole BODIPY 2 was also reactive under Suzuki and Stille cross-coupling reactions, the latter producing the targeted 3,5-functionalized products in higher yields. The spectroscopic properties of the fluorinated BODIPYs were investigated in THF solution. The starting tetrafluoroisoindole BODIPY 1 showed typical BODIPY spectra with absorption and emission at 560 and $568 \mathrm{~nm}$, respectively, and very high fluorescence quantum yield $(\Phi=$ 0.98). Functionalization at the 3- and or 5-positions with phenyl, phenol, or piperidine resulted in red-shifted spectra, retaining of high fluorescence quantum yields, and, in the case of piperidine, lower molar absorptivity. On the other hand, disubstitution (and in the case of $\mathbf{5 d}$, trisubstitution) with furyl, benzothio, and methylphenylthio groups significantly decreased the fluorescence quantum yields. Isoindole BODIPYs 3a and $\mathbf{4 a}$ with trialkylpyrrole substituents showed the largest red-shifted absorptions but were nonfluorescent in THF. The unusual product bisBODIPY $\mathbf{6}$ showed unique spectroscopic properties, significantly different from those of the monomeric BODIPYs, displaying two major absorption bands at 517 and $602 \mathrm{~nm}$ and very low fluorescence quantum yield.

\section{EXPERIMENTAL SECTION}

Silica gel 60 (70-230 mesh, Sigma-Aldrich) was used for column chromatography. Reagents and solvents were of the highest grade commercially available and were used without further purification. Dry solvents were collected from a PS-400 Solvent Purification System 
(Innovative Technology, Inc.). ${ }^{1} \mathrm{H},{ }^{13} \mathrm{C},{ }^{11} \mathrm{~B}$, and ${ }^{19} \mathrm{~F}$ NMR spectra were recorded with a Bruker DPX-400 (400 MHz) or a Bruker DPX-500 (500 MHz) spectrometer. Experiments were performed in $\mathrm{CDCl}_{3}$ at $300 \mathrm{~K}$. Chemical shifts are expressed in ppm relative to TMS. High resolution mass spectra were obtained using ESI-TOF. UV-vis spectra were recorded in THF on a Varian Cary 50 spectrophotometer. Melting points were determined in an open capillary and are uncorrected. Fluorescence spectra were recorded in THF on a Fluorolog-3 Modular spectrofluorometer. The relative fluorescence quantum yields were obtained by comparing the area under the corrected emission spectrum of a test sample with that of rhodamine $6 \mathrm{G}$ ( 0.80 in methanol) or methylene blue ( 0.03 in methanol) as external standards. ${ }^{24}$ All spectra were recorded at room temperature using nondegassed samples, spectroscopic grade solvents, and a $10 \mathrm{~mm}$ quartz cuvette. Dilute solutions $(0.01<A<0.05)$ were used to minimize the reabsorption effects, and in all cases, correction for the refractive index was applied. 4,5,6,7-Tetrafluoroisoindole ${ }^{15}$ and 3,4-dimethyl- $1 H$-pyrrole-2carbaldehyde ${ }^{25}$ were prepared following literature methods, and in each case, the characterization data were in agreement with reported data.

\section{X-ray Crystallographic Data.}

Diffraction data were collected at low temperature (100 K for $\mathbf{1}, 105 \mathrm{~K}$ for $\mathbf{7}$ and $\mathbf{4 e}, 110 \mathrm{~K}$ for $\mathbf{6}$ and 4d) on a Bruker Kappa Apex-II DUO diffractometer with MoKa (for $\mathbf{1}$ and 6) radiation $(\lambda=0.71073 \AA$ ) or CuKa (for $7, \mathbf{4 d}$, and $\mathbf{4 e}$ ) radiation $(\lambda=1.54184 \AA$ ).

Refinement was by full-matrix least-squares using SHELXL, with hydrogen atoms in idealized positions. Disordered solvent contribution was removed using the SQUEEZE procedure for $\mathbf{6}, \mathbf{4 d}$, and $\mathbf{4 e}$. The structure of $\mathbf{7}$ has three independent molecules, and the crystal was a twin. The structure of $\mathbf{4 d}$ has two independent molecules, both of which have disorder of one of the benzyl groups, and the crystal was also a twin. CCDC 15896241589628.

BODIPY 1.- $150 \mu \mathrm{L}$ of $\mathrm{POCl}_{3}$ (1.59 mmol) was added to a stirring solution of 4,5,6,7tetrafluoroisoindole (100 mg, $0.53 \mathrm{mmol})$ and 3,4-dimethyl-1 $H$-pyrrole-2-carbaldehyde (65.1 mg, $0.53 \mathrm{mmol}$ ) in $12 \mathrm{~mL}$ of $\mathrm{CH}_{2} \mathrm{Cl}_{2}$ at $0{ }^{\circ} \mathrm{C}$ under $\mathrm{N}_{2}$. After $2 \mathrm{~h}$ stirring, another 35 mL $\mathrm{CH}_{2} \mathrm{Cl}_{2}$ was added and $1.12 \mathrm{~mL}$ of TEA $(7.95 \mathrm{mmol})$ was slowly added to the solution always at $0{ }^{\circ} \mathrm{C}$. Finally $1.96 \mathrm{~mL}$ of $\mathrm{BF}_{3} \cdot \mathrm{Et}_{2} \mathrm{O}(15.90 \mathrm{mmol})$ was slowly added. The solution was stirred at $0{ }^{\circ} \mathrm{C}$ for $15 \mathrm{~min}$, warmed up to r.t., and left stirring for another $6 \mathrm{~h}$. The solvent was removed under reduced pressure, and the residue was chromatographed on a silica gel column using $\mathrm{CH}_{2} \mathrm{Cl}_{2}$ as eluent, obtaining $108.8 \mathrm{mg}$ of pure product. Yield $=60 \%$. m.p.: 275-277 ${ }^{\circ} \mathrm{C}$. UV-vis (THF): $\lambda_{\max }, \mathrm{nm}(\log \varepsilon) 522$ (sh, 4.34), 540 (sh, 4.54), 560 (4.76). ${ }^{1} \mathrm{H}$ NMR (400 MHz, $\mathrm{CDCl}_{3}$ ): $\delta$, ppm $8.36(\mathrm{~s}, 1 \mathrm{H}), 7.64(\mathrm{~s}, 1 \mathrm{H}), 7.61(\mathrm{~s}, 1 \mathrm{H}), 2.27\left(\mathrm{~s}, 3 \mathrm{H}, \mathrm{CH}_{3}\right)$, $2.06\left(\mathrm{~s}, 3 \mathrm{H}, \mathrm{CH}_{3}\right) .{ }^{13} \mathrm{C} \mathrm{NMR}\left(125 \mathrm{MHz}, \mathrm{CDCl}_{3}\right): \delta$, ppm 167.4, 145.3, 134.7, 132.5, 128.8, $123.9,68.2,38.8,30.4,28.9,23.8,22.9,14.0,10.9,9.8 .{ }^{19} \mathrm{~F} \mathrm{NMR}\left(376 \mathrm{MHz}, \mathrm{CDCl}_{3}\right): \delta$, ppm $-142.46\left(\mathrm{dt}, 1 \mathrm{~F}, J^{\prime}=3.96 \mathrm{~Hz}, J^{\prime \prime}=18.69 \mathrm{~Hz}\right),-143.58\left(\mathrm{q}, 2 \mathrm{~F}, J^{\prime}=28.73 \mathrm{~Hz}\right)$, $-147.06\left(\mathrm{t}, 1 \mathrm{~F}, J^{\prime}=18.84 \mathrm{~Hz}\right),-151.48\left(\mathrm{dt}, 1 \mathrm{~F}, J^{\prime}=3.38 \mathrm{~Hz}, J^{\prime \prime}=18.50 \mathrm{~Hz}\right),-159.28(\mathrm{t}$, $\left.1 \mathrm{~F}, J^{\prime}=18.42 \mathrm{~Hz}\right) .{ }^{11} \mathrm{~B} \mathrm{NMR}\left(128 \mathrm{MHz}, \mathrm{CDCl}_{3}\right): \delta$, ppm 0.28 (t, 1B, $\left.J=28.6 \mathrm{~Hz}\right)$. HRMS (ESI-TOF) $\mathrm{m} / z[\mathrm{M}+\mathrm{H}]^{+}$calcd for $\mathrm{C}_{15} \mathrm{H}_{9} \mathrm{BF}_{6} \mathrm{~N}_{2} 342.0872$; found 342.0873 . 
BODIPY 2.-22.4 $\mu \mathrm{L}$ of $\mathrm{Br}_{2}(0.438 \mathrm{mmol})$ was slowly added to a stirring solution of $50 \mathrm{mg}$ of BODIPY $(0.146 \mathrm{mmol})$ in $8 \mathrm{~mL}$ of $\mathrm{CH}_{2} \mathrm{Cl}_{2}$ at $0{ }^{\circ} \mathrm{C}$. After $20 \mathrm{~min}$ stirring, no starting material was detected by UV-vis spectroscopy and TLC. $40 \mathrm{~mL}$ of $\mathrm{Na}_{2} \mathrm{~S}_{2} \mathrm{O}_{3}$ sat. aq. was added to the solution, and the mixture was extracted with $\mathrm{CH}_{2} \mathrm{Cl}_{2}$. The organic phase was dried over anhydrous sodium sulfate. The product was not soluble in common organic solvents to allow further purification, so it was recrystallized from $\mathrm{CH}_{2} \mathrm{Cl}_{2} /$ hexane, obtaining $67.9 \mathrm{mg}$ of pure product, and considered pure based on TLC analysis. Yield $=93 \%$. m.p.: 267-269 ${ }^{\circ} \mathrm{C}$. UV-vis (THF): $\lambda_{\max }, \mathrm{nm}$ 588. HRMS (ESI-TOF) $\mathrm{m} / \mathrm{z}\left[\mathrm{M}^{*}\right]^{-}$calcd for $\mathrm{C}_{15} \mathrm{H}_{7} \mathrm{BBr}_{2} \mathrm{~F}_{6} \mathrm{~N}_{2}$ 497.8979; found 497.8969 .

BODIPY 3a.-A solution of BODIPY $2(15 \mathrm{mg}, 0.03 \mathrm{mmol})$ and $20.3 \mu \mathrm{L}$ of 3-ethyl-2,4dimethylpyrrole $(0.15 \mathrm{mmol})$ in $3 \mathrm{~mL}$ of toluene was stirred at $80^{\circ} \mathrm{C}$ for $10 \mathrm{~min}$. The solvent was removed under reduced pressure, and the residue was chromatographed on a silica gel column using $\mathrm{CH}_{2} \mathrm{Cl}_{2} /$ hexane $1 / 1$ as eluent, obtaining $9.8 \mathrm{mg}$ of pure product. Yield $=60 \%$. m.p.: 193-194 ${ }^{\circ} \mathrm{C}$. UV-vis (THF): $\lambda_{\max }, \mathrm{nm}(\log \varepsilon) 464$ (4.14), 615 (sh, 4.47), 654 (4.76). ${ }^{1} \mathrm{H}$ NMR (400 MHz, $\mathrm{CDCl}_{3}$ ): $\delta$, ppm $9.51(2 \mathrm{~s}, 1 \mathrm{H}, \mathrm{NH}), 7.32$ (s, 1H, CHmeso), 2.45 (q, 2H, $\left.J=7.64 \mathrm{~Hz}, \mathrm{CH}_{2} \mathrm{CH}_{3}\right), 2.35\left(\mathrm{~s}, 3 \mathrm{H}, \mathrm{CH}_{3}\right), 2.24\left(\mathrm{~s}, 3 \mathrm{H}, \mathrm{CH}_{3}\right), 2.17\left(\mathrm{~s}, 3 \mathrm{H}, \mathrm{CH}_{3}\right), 2.01(\mathrm{~s}, 3 \mathrm{H}$, $\left.\mathrm{CH}_{3}\right), 1.12$ (t, $\left.3 \mathrm{H}, J=7.64 \mathrm{~Hz}, \mathrm{CH}_{2} \mathrm{CH}_{3}\right) .{ }^{13} \mathrm{C} \mathrm{NMR}\left(125 \mathrm{MHz}, \mathrm{CDCl}_{3}\right): \delta$, ppm 133.7, 133.4, 132.1, 132.0, 129.1,129.1, 126.0, 125.7, 124.6, 116.8, 116.7, 116.6, 116.5, 110.3, $31.7,30.9,17.7,14.9,12.0,11.4,11.3,10.1,9.9 .{ }^{19} \mathrm{~F} \mathrm{NMR}\left(376 \mathrm{MHz}, \mathrm{CDCl}_{3}\right): \delta$, ppm $-123.98\left(\mathrm{dq}, 1 \mathrm{~F}, J^{\prime}=34.55 \mathrm{~Hz}, J^{\prime \prime}=94.94 \mathrm{~Hz}\right),-137.31\left(\mathrm{dt}, 1 \mathrm{~F}, J^{\prime}=6.39 \mathrm{~Hz}, J^{\prime \prime}=18.54\right.$ $\mathrm{Hz}),-147.27(\mathrm{t}, 1 \mathrm{~F}, J=19.55 \mathrm{~Hz}),-150.83\left(\mathrm{dt}, 1 \mathrm{~F}, J^{\prime}=6.00 \mathrm{~Hz}, J^{\prime \prime}=19.51 \mathrm{~Hz}\right),-151.84$ $\left(\mathrm{dq}, 1 \mathrm{~F}, J^{\prime}=27.79 \mathrm{~Hz}, J^{\prime \prime}=94.86 \mathrm{~Hz}\right),-158.41(\mathrm{t}, 1 \mathrm{~F}, J=19.06 \mathrm{~Hz}) .{ }^{11} \mathrm{~B}$ NMR $(128$ $\mathrm{MHz}, \mathrm{CDCl}_{3}$ ): $\delta$, ppm 1.01 (t, $1 \mathrm{~B}, J=31.9 \mathrm{~Hz}$ ). HRMS (ESI-TOF) $\mathrm{m} / z[\mathrm{M}-\mathrm{HF}]^{+}$calcd for $\mathrm{C}_{23} \mathrm{H}_{18} \mathrm{BBrF}_{5} \mathrm{~N}_{3}$ 521.0806; found 521.0805.

BODIPY 3b. $-17.8 \mu \mathrm{L}$ of piperidine $(0.18 \mathrm{mmol})$ was added to a stirring solution of BODIPY 2 ( $15 \mathrm{mg}, 0.03 \mathrm{mmol})$ in $3 \mathrm{~mL}$ of THF. The solution was left stirring at r.t. for 15 $\min$. The solvent was removed under reduced pressure, and the residue was chromatographed on a silica gel column using $\mathrm{CH}_{2} \mathrm{Cl}_{2}$ /hexane 7:3 as eluent, obtaining 14.1 mg of pure product. Yield $=93 \%$. m.p.: $207-209^{\circ} \mathrm{C}$. UV-vis $(\mathrm{THF}): \lambda_{\max }, \mathrm{nm}(\log \varepsilon) 488$ (sh, 4.02), 528 (sh, 4.23), 562 (4.36). ${ }^{1} \mathrm{H}$ NMR (400 MHz, $\mathrm{CDCl}_{3}$ ): $\delta$, ppm $7.06(\mathrm{~s}, 1 \mathrm{H}$, $\mathrm{CH}$ meso), 3.82 (m, 4H, piperidine), $2.17\left(\mathrm{~s}, 3 \mathrm{H}, \mathrm{CH}_{3}\right), 1.98\left(\mathrm{~s}, 3 \mathrm{H}, \mathrm{CH}_{3}\right), 1.85(\mathrm{~m}, 4 \mathrm{H}$, piperidine), 1.74 (m, 2H, piperidine). ${ }^{13} \mathrm{C}$ NMR (125 $\left.\mathrm{MHz}, \mathrm{CDCl}_{3}\right): \delta$, ppm 157.4, 140.8, 128.7, 124.5, 123.9, 120.8, 117.3, 113.5,113.4, 111.6, 53.8, 53.8, 53.7, 53.7, 29.7, 25.9, 25.9, 23.6, 9.9, 9.8. ${ }^{19} \mathrm{~F}$ NMR $\left(376 \mathrm{MHz}, \mathrm{CDCl}_{3}\right): \delta, \mathrm{ppm}-133.09\left(\mathrm{dt}, 1 \mathrm{~F}, J^{\prime}=7.76 \mathrm{~Hz}, J^{\prime \prime}\right.$ $=19.14 \mathrm{~Hz}),-133.76\left(\mathrm{q}, 2 \mathrm{~F}, J^{\prime}=32.90 \mathrm{~Hz}\right),-146.06\left(\mathrm{t}, 1 \mathrm{~F}, J^{\prime}=20.04 \mathrm{~Hz}\right),-149.70(\mathrm{dt}, 1 \mathrm{~F}$, $\left.J^{\prime}=7.88 \mathrm{~Hz}, J^{\prime \prime}=20.15 \mathrm{~Hz}\right),-158.42\left(\mathrm{t}, 1 \mathrm{~F}, J^{\prime}=19.82 \mathrm{~Hz}\right) .{ }^{11} \mathrm{~B} \mathrm{NMR}(128 \mathrm{MHz}$, $\mathrm{CDCl}_{3}$ ): $\delta$, ppm 1.07 (t, 1B, $J=32.1 \mathrm{~Hz}$ ). HRMS (ESI-TOF) $\mathrm{m} / z[\mathrm{M}+\mathrm{H}]^{+}$calcd for $\mathrm{C}_{20} \mathrm{H}_{17} \mathrm{BBrF}_{6} \mathrm{~N}_{3}$ 503.0712; found 503.0700.

BODIPY 3c.-24 $\mathrm{mg}$ of $\mathrm{K}_{2} \mathrm{CO}_{3}(0.18 \mathrm{mmol})$ was added to a stirring solution of BODIPY 2 (15 mg, $0.03 \mathrm{mmol}$ ) and 4-methoxyphenol $(10.8 \mathrm{mg}, 0.09 \mathrm{mmol})$ in $3 \mathrm{~mL}$ of THF/ $\mathrm{CH}_{3} \mathrm{CN}$ 1:1. The solution was left stirring at r.t. for $40 \mathrm{~min}$. The solvent was removed under reduced pressure, and the residue was chromatographed on a silica gel column using $\mathrm{CH}_{2} \mathrm{Cl}_{2}$ /hexane 
1/1 as eluent, obtaining $5.7 \mathrm{mg}$ of pure product. Yield $=35 \%$. m.p.: $190-192{ }^{\circ} \mathrm{C}$. UV-vis (THF): $\lambda_{\max }, \mathrm{nm}(\log \varepsilon) 536$ (sh, 4.33), 570 (4.80). ${ }^{1} \mathrm{H}$ NMR (500 MHz, $\mathrm{CDCl}_{3}$ ): $\delta$, ppm 7.38 (s, 1H, CHmeso), 7.07 (d, 1H, $J=9.07 \mathrm{~Hz}, \mathrm{Ph}$ ), 6.87 (d, 1H, $J=9.07 \mathrm{~Hz}, \mathrm{Ph}), 3.80$ (s, $3 \mathrm{H}, \mathrm{OCH} 3), 2.26$ (s, 3H, CH3), 2.01 (s, 3H, CH3). ${ }^{13} \mathrm{C} \mathrm{NMR}\left(125 \mathrm{MHz}, \mathrm{CDCl}_{3}\right): \delta, \mathrm{ppm}$ $157.2,150.2,135.9,132.3,126.6,119.8,118.9,117.9,116.0,114.9,114.8,114.6,103.2$, 98.5, 67.9, 55.8, 55.7, 32.7, 23.5, 14.1, 10.2, 9.9. $\left.{ }^{19} \mathrm{~F} \mathrm{NMR} \mathrm{(376} \mathrm{MHz,} \mathrm{CDCl}_{3}\right): \delta$, ppm $-133.75\left(\mathrm{dt}, 1 \mathrm{~F}, J^{\prime}=6.16 \mathrm{~Hz}, J^{\prime \prime}=20.27 \mathrm{~Hz}\right),-145.20\left(\mathrm{q}, 2 \mathrm{~F}, J^{\prime}=29.18 \mathrm{~Hz}\right),-145.63(\mathrm{t}$, $\left.1 \mathrm{~F}, J^{\prime}=20.16 \mathrm{~Hz}\right),-148.49\left(\mathrm{dt}, 1 \mathrm{~F}, J^{\prime}=5.68 \mathrm{~Hz}, J^{\prime \prime}=19.18 \mathrm{~Hz}\right),-157.69\left(\mathrm{t}, 1 \mathrm{~F}, J^{\prime}=\right.$ $19.74 \mathrm{~Hz}) .{ }^{11} \mathrm{~B}$ NMR $\left(128 \mathrm{MHz}, \mathrm{CDCl}_{3}\right): \delta$, ppm 0.62 (t, 1B, $J=27.1 \mathrm{~Hz}$ ). HRMS (ESITOF) $\mathrm{m} / z[\mathrm{~m}+\mathrm{H}]^{+}$calcd for $\mathrm{C}_{22} \mathrm{H}_{14} \mathrm{BBrF}_{6} \mathrm{~N}_{2} \mathrm{O}_{2}$ 542.0345; found 542.0317 .

BODIPY 4a.-A solution of BODIPY $2(15 \mathrm{mg}, 0.03 \mathrm{mmol})$ and $20.3 \mu \mathrm{L}$ of 3-ethyl-2,4dimethylpyrrole $(0.30 \mathrm{mmol})$ in $3 \mathrm{~mL}$ of toluene was stirred at $80^{\circ} \mathrm{C}$ for $60 \mathrm{~min}$. The solvent was removed under reduced pressure, and the residue was chromatographed on a silica gel column using $\mathrm{CH}_{2} \mathrm{Cl}_{2} /$ hexane $1 / 1$ as eluent, obtaining $13.5 \mathrm{mg}$ of pure product. Yield = 77\%. m.p.: $153-155^{\circ} \mathrm{C}$. UV-vis (THF): $\lambda_{\max }, \mathrm{nm}(\log \varepsilon) 475$ (3.73), 645 (sh, 4.36 ), 690 (4.67). ${ }^{1} \mathrm{H}$ NMR $\left(500 \mathrm{MHz}, \mathrm{CDCl}_{3}\right): \delta$, ppm $9.58(2 \mathrm{~s}, 1 \mathrm{H}, \mathrm{NH}), 8.20(\mathrm{~s}, 1 \mathrm{H}, \mathrm{NH}), 7.33$ (s, $1 \mathrm{H}, \mathrm{CH}$ meso), 2.48 (q, $2 \mathrm{H}, J=7.56 \mathrm{~Hz}, \mathrm{CH}_{2} \mathrm{CH}_{3}$ ), 2.36 (s, 3H, $\mathrm{CH}_{3}$ ), 2.34 (q, $2 \mathrm{H}, J=7.52$ $\mathrm{Hz}, \mathrm{CH}_{2} \mathrm{CH}_{3}$ ), 2.17 (s, 3H, $\left.\mathrm{CH}_{3}\right), 2.14$ (s, 3H, $\left.\mathrm{CH}_{3}\right), 2.12\left(2 \mathrm{~s}, 3 \mathrm{H}, \mathrm{CH}_{3}\right), 2.09$ (s, 3H, $\mathrm{CH}_{3}$ ), $1.88\left(\mathrm{~s}, 3 \mathrm{H}, \mathrm{CH}_{3}\right), 1.14$ (t, $\left.3 \mathrm{H}, J=7.56 \mathrm{~Hz}, \mathrm{CH}_{2} \mathrm{CH}_{3}\right), 1.02\left(\mathrm{t}, 3 \mathrm{H}, J=7.52 \mathrm{~Hz}, \mathrm{CH}_{2} \mathrm{CH}_{3}\right)$. ${ }^{13} \mathrm{C}$ NMR $\left(125 \mathrm{MHz}, \mathrm{CDCl}_{3}\right): \delta$, ppm 147.5, 144.8, 137.3, 134.5, 132.9, 132.5, 129.7, 128.4, 126.7, 125.4, 123.9, 121.8, 108.9, 67.9, 17.9, 17.7, 17.7, 15.4, 14.9, 14.9, 14.8, 12.1, $12.0,11.9,11.4,11.4,11.3,10.9,9.9,9.6,9.5 .{ }^{19} \mathrm{~F}$ NMR $\left(376 \mathrm{MHz}, \mathrm{CDCl}_{3}\right): \delta, \mathrm{ppm}$ $-118.58(\mathrm{~m}, 1 \mathrm{~F}),-137.88\left(\mathrm{dt}, 1 \mathrm{~F}, J^{\prime}=5.84 \mathrm{~Hz}, J^{\prime \prime}=19.80 \mathrm{~Hz}\right),-146.41(\mathrm{~m}, 1 \mathrm{~F}),-147.57$ $(\mathrm{t}, 1 \mathrm{~F}, J=19.51 \mathrm{~Hz}),-151.60\left(\mathrm{dt}, 1 \mathrm{~F}, J^{\prime}=5.40 \mathrm{~Hz}, J^{\prime \prime}=19.40 \mathrm{~Hz}\right),-158.94(\mathrm{t}, 1 \mathrm{~F}, J=$ $20.16 \mathrm{~Hz}) .{ }^{11} \mathrm{~B}$ NMR $\left(128 \mathrm{MHz}, \mathrm{CDCl}_{3}\right): \delta$, ppm 1.32 (t, 1B, $J=32.4 \mathrm{~Hz}$ ). HRMS (ESITOF) $\mathrm{m} / z\left[\mathrm{M}^{*}\right]^{+}$calcd for $\mathrm{C}_{31} \mathrm{H}_{31} \mathrm{BF}_{6} \mathrm{~N}_{4}$ 583.2577; found 583.2573.

BODIPY 4d.-8.4 $\mu \mathrm{L}$ of TEA ( $0.06 \mathrm{mmol})$ was added to a solution of BODIPY $2(15 \mathrm{mg}$, $0.03 \mathrm{mmol})$ and 4-methylbenzenethiol $(7.5 \mathrm{mg}, 0.06 \mathrm{mmol})$ in $3 \mathrm{~mL}$ of THF. The solution was left stirring at r.t. for $3 \mathrm{~min}$. The solvent was removed under reduced pressure, and the residue was chromatographed on a silica gel column using $\mathrm{CH}_{2} \mathrm{Cl}_{2} /$ hexane $1 / 1$ as eluent, obtaining $4.4 \mathrm{mg}$ of pure product. Yield $=25 \%$. m.p.: $222-224^{\circ} \mathrm{C}$. UV-vis (THF): $\lambda_{\max }, \mathrm{nm}$ (log ع) 592 (sh, 4.50), 629 (4.86). ${ }^{1} \mathrm{H}$ NMR (400 MHz, $\mathrm{CDCl}_{3}$ ): $\delta, \mathrm{ppm} 7.43(\mathrm{~s}, 1 \mathrm{H}$, CHmeso), 7.37 (d, 2H, $J=8.00 \mathrm{~Hz}, \mathrm{Ph}), 7.3(5$ (d, 2H, $J=8.08 \mathrm{~Hz}, \mathrm{Ph}), 7.14$ (d, 2H, $J=7.96$ $\mathrm{Hz}, \mathrm{Ph}), 7.10(\mathrm{~d}, 2 \mathrm{H}, J=8.00 \mathrm{~Hz}, \mathrm{Ph}), 2.35\left(\mathrm{~s}, 3 \mathrm{H}, \mathrm{CH}_{3}\right), 2.33\left(\mathrm{~s}, 3 \mathrm{H}, \mathrm{CH}_{3}\right), 2.22(\mathrm{~s}, 3 \mathrm{H}$, $\left.\mathrm{CH}_{3}\right), 1.67$ (s, 3H, $\left.\mathrm{CH}_{3}\right) .{ }^{13} \mathrm{C} \mathrm{NMR}\left(125 \mathrm{MHz}, \mathrm{CDCl}_{3}\right): \delta$, ppm 194.1, 187.1, 160.2, 154.9, 153.0, 139.1, 138.3, 137.9, 135.0, 134.7, 131.5, 131.4, 131.3, 130.4, 130.1, 130.1, 129.4, $118.9,88.1,53.4,29.7,21.2,10.1,9.9 .{ }^{19} \mathrm{~F} \mathrm{NMR}\left(376 \mathrm{MHz}, \mathrm{CDCl}_{3}\right): \delta, \mathrm{ppm}-137.16$ (q, $2 \mathrm{~F}, J=30.34 \mathrm{~Hz}),-140.06\left(\mathrm{dt}, 1 \mathrm{~F}, J^{\prime}=4.56 \mathrm{~Hz}, J^{\prime \prime}=20.36 \mathrm{~Hz}\right),-147.79(\mathrm{t}, 1 \mathrm{~F}, J=19.21$ $\mathrm{Hz}),-152.46\left(\mathrm{dt}, 1 \mathrm{~F}, J^{\prime}=4.48 \mathrm{~Hz}, J^{\prime \prime}=19.44 \mathrm{~Hz}\right),-158.98(\mathrm{t}, 1 \mathrm{~F}, J=20.20 \mathrm{~Hz}) .{ }^{11} \mathrm{~B}$ NMR $\left(128 \mathrm{MHz}, \mathrm{CDCl}_{3}\right.$ ): $\delta$, ppm 1.09 (t, 1B, $J=29.2 \mathrm{~Hz}$ ). HRMS (ESI-TOF) $\mathrm{m} / \mathrm{z}\left[\mathrm{M}^{*}\right]^{+}$calcd for $\mathrm{C}_{29} \mathrm{H}_{21} \mathrm{BF}_{6} \mathrm{~N}_{2} \mathrm{~S}_{2}$ 586.1152; found 586.1162. 
BODIPY 4e.- $12.5 \mu \mathrm{L}$ of TEA ( $0.09 \mathrm{mmol})$ was added to a solution of BODIPY 2 (15 mg, $0.03 \mathrm{mmol})$ and $10.6 \mu \mathrm{L}$ of benzylmercaptan $(0.09 \mathrm{mmol})$ in $3 \mathrm{~mL}$ of THF. The solution was left stirring at r.t. for $15 \mathrm{~min}$. The solvent was removed under reduced pressure, and the residue was chromatographed on a silica gel column using $\mathrm{CH}_{2} \mathrm{Cl}_{2} /$ hexane $1 / 1$ as eluent, obtaining $7.0 \mathrm{mg}$ of pure product. Yield $=40 \%$. m.p.: $167-168^{\circ} \mathrm{C}$. UV-vis (THF): $\lambda_{\max }, \mathrm{nm}$ (log $\varepsilon) 582$ (sh, 4.53), 610 (4.81). ${ }^{1} \mathrm{H}$ NMR (400 MHz, $\mathrm{CDCl}_{3}$ ): $\delta$, ppm $7.35(\mathrm{~s}, 1 \mathrm{H}$, CHmeso), 7.33-7.15 (m, 10H, Ph), 4.48 (s, 2H, CH $), 4.33$ (s, 2H, $\left.\mathrm{CH}_{2}\right), 2.17$ (s, 3H, $\mathrm{CH}_{3}$ ), $1.75\left(\mathrm{~s}, 3 \mathrm{H}, \mathrm{CH}_{3}\right) .{ }^{13} \mathrm{C} \mathrm{NMR}\left(125 \mathrm{MHz}, \mathrm{CDCl}_{3}\right): \delta$, ppm 206.9, 157.3, 152.2, 137.8, 137.2, $135.8,135.5,133.3,129.4,129.3,128.5,128.5,127.7,127.5,126.9,118.9,53.4,42.3$, $41.2,41.1,41.1,31.9,31.6,30.9,29.7,22.7,14.1,10.0,9.7 .{ }^{19} \mathrm{~F} \mathrm{NMR}\left(376 \mathrm{MHz}, \mathrm{CDCl}_{3}\right): \delta$, ppm -136.59 (q, 2F, $J=30.16 \mathrm{~Hz}),-142.88\left(\mathrm{dt}, 1 \mathrm{~F}, J^{\prime}=4.84 \mathrm{~Hz}, J^{\prime \prime}=20.04 \mathrm{~Hz}\right),-147.56$ $(\mathrm{t}, 1 \mathrm{~F}, J=19.21 \mathrm{~Hz}),-152.05\left(\mathrm{dt}, 1 \mathrm{~F}, J^{\prime}=4.96 \mathrm{~Hz}, J^{\prime \prime}=20.00 \mathrm{~Hz}\right),-158.90(\mathrm{t}, 1 \mathrm{~F}, J=$ $19.80 \mathrm{~Hz}) .{ }^{11} \mathrm{~B}$ NMR $\left(128 \mathrm{MHz}, \mathrm{CDCl}_{3}\right): \delta$, ppm 1.09 (t, 1B, $J=29.0 \mathrm{~Hz}$ ). HRMS (ESITOF) $\mathrm{m} / \mathrm{z}[\mathrm{M}-\mathrm{F}]^{+}$calcd for $\mathrm{C}_{29} \mathrm{H}_{21} \mathrm{BF}_{6} \mathrm{~N}_{2} \mathrm{~S}_{2}$ 567.1159; found 567.1154.

BODIPY 5d.-23 $\mu \mathrm{L}$ of TEA ( $0.17 \mathrm{mmol})$ was added to a solution of BODIPY 2 (30 $\mathrm{mg}$, $0.06 \mathrm{mmol}$ ) and 4-methylbenzenethiol $(20.7 \mathrm{mg}, 0.18 \mathrm{mmol})$ in $3 \mathrm{~mL}$ of THF. The solution was left stirring at r.t. for $3 \mathrm{~min}$. The solvent was removed under reduced pressure, and the residue was chromatographed on a silica gel column using $\mathrm{CH}_{2} \mathrm{Cl}_{2} /$ hexane 1:1 as eluent, obtaining $36.2 \mathrm{mg}$ of pure product. Yield $=75 \%$. m.p.: $210-212{ }^{\circ} \mathrm{C}$. UV-vis (THF): $\lambda_{\max }$, $\mathrm{nm}(\log \varepsilon) 606$ (sh, 4.47), 646 (4.87). ${ }^{1} \mathrm{H}$ NMR (125 MHz, $\left.\mathrm{CDCl}_{3}\right): \delta$, ppm 7.43 (s, $1 \mathrm{H}$, CHmeso), 7.37 (d, 2H, $J=8.10 \mathrm{~Hz}, \mathrm{Ph}), 7.34(\mathrm{~d}, 2 \mathrm{H}, J=8.10 \mathrm{~Hz}, \mathrm{Ph}), 7.29(\mathrm{~d}, 2 \mathrm{H}, J=8.15$ $\mathrm{Hz}, \mathrm{Ph}$ ), 7.11 (d, 2H, $J=8.65 \mathrm{~Hz}, \mathrm{Ph}$ ), 7.09 (d, 2H, $J=8.65 \mathrm{~Hz}, \mathrm{Ph}), 7.07$ (d, 2H, $J=8.25$ $\mathrm{Hz}, \mathrm{Ph}$ ), 2.33 (s, 3H, $\mathrm{CH}_{3}$ ), 2.31 (s, 3H, $\left.\mathrm{CH}_{3}\right), 2.30$ (s, 3H, $\left.\mathrm{CH}_{3}\right), 2.17$ (s, 3H, $\left.\mathrm{CH}_{3}\right), 1.64$ (s, $\left.3 \mathrm{H}, \mathrm{CH}_{3}\right) .{ }^{13} \mathrm{C} \mathrm{NMR}\left(500 \mathrm{MHz}, \mathrm{CDCl}_{3}\right): \delta$, ppm 173.9, 153.1, 151.2, 144.1, 139.0, 138.2, $137.9,137.9,135.4,131.5,131.4,130.9,130.5,130.0,129.9,129.4,125.9,118.7,118.6$, 113.9, 65.1, 31.9, 29.7, 29.7, 29.6, 29.5, 29.4, 29.3, 29.1, 24.9, 22.7, 21.2, 21.1, 14.1, 10.1, 9.9. ${ }^{19} \mathrm{~F}$ NMR (376 MHz, $\mathrm{CDCl}_{3}$ ): $\delta, \mathrm{ppm}-115.14(\mathrm{~d}, 1 \mathrm{~F}, J=20.91 \mathrm{~Hz}),-134.08(\mathrm{~d}, 1 \mathrm{~F}, J=$ $21.13 \mathrm{~Hz}),-137.24(\mathrm{q}, 2 \mathrm{~F}, J=30.83 \mathrm{~Hz}),-142.58(\mathrm{t}, 1 \mathrm{~F}, J=21.10 \mathrm{~Hz}) .{ }^{11} \mathrm{~B}$ NMR $(128$ $\mathrm{MHz}, \mathrm{CDCl}_{3}$ ): $\delta$, ppm 1.10 (t, 1B, $J=28.6 \mathrm{~Hz}$ ). HRMS (ESI-TOF) $\mathrm{m} / z[\mathrm{M}+\mathrm{H}]^{+}$calcd for $\mathrm{C}_{36} \mathrm{H}_{28} \mathrm{BF}_{5} \mathrm{~N}_{2} \mathrm{~S}_{3}$ 691.1506; found 691.1522 .

bisBODIPY 6. $-828 \mu \mathrm{L}$ of aniline $(0.09 \mathrm{mmol})$ was added to a stirring solution of BODIPY 2 ( $15 \mathrm{mg}, 0.03 \mathrm{mmol}$ ) in $3 \mathrm{~mL}$ of THF. The solution was left stirring at r.t. for $1 \mathrm{~h}$. The solvent was removed under reduced pressure, and the residue was chromatographed on a silica gel column using $\mathrm{CH}_{2} \mathrm{Cl}_{2} /$ hexane $1 / 1$ as eluent, obtaining $8.4 \mathrm{mg}$ of pure product. Yield $=65 \%$. m.p.: $177-179{ }^{\circ} \mathrm{C}$. UV-vis (THF): $\lambda_{\max }, \mathrm{nm}(\log \varepsilon) 517(4.31), 602(4.32) .{ }^{1} \mathrm{H}$ NMR (500 MHz, CDCl $)_{3}$ ) $\delta$, ppm 8.29 (m, 2H, NH), 7.34 (t, 4H, $\left.J=7.90 \mathrm{~Hz}, \mathrm{Ph}\right), 7.30$ $7.27\left(\mathrm{~m}, 4 \mathrm{H}, \mathrm{Ph}+\mathrm{CH}\right.$ meso), $7.10(\mathrm{~d}, 4 \mathrm{H}, J=7.65 \mathrm{~Hz}, \mathrm{Ph}), 2.27\left(\mathrm{~s}, 6 \mathrm{H}, \mathrm{CH}_{3}\right), 1.91(\mathrm{~s}, 6 \mathrm{H}$, $\left.\mathrm{CH}_{3}\right) .{ }^{13} \mathrm{C}$ NMR $\left(125 \mathrm{MHz}, \mathrm{CDCl}_{3}\right): \delta$, ppm 167.8, 151.8, 138.3, 137.1, 132.5, 130.9, 130.7, $130.2,129.5,128.8,127.3,126.6,124.2,124.1,123.3,115.5,115.4,10.9,9.9,9.5,9.5 .{ }^{19} \mathrm{~F}$ $\operatorname{NMR}\left(376 \mathrm{MHz}, \mathrm{CDCl}_{3}\right): \delta, \mathrm{ppm}-127.32\left(\mathrm{dt}, 1 \mathrm{~F}, J^{\prime}=7.52 \mathrm{~Hz}, J^{\prime \prime}=23.16 \mathrm{~Hz}\right),-141.67$ $(\mathrm{m}, 1 \mathrm{~F}),-145.68\left(\mathrm{t}, 1 \mathrm{~F}, J^{\prime}=20.40 \mathrm{~Hz}\right),-146.70(\mathrm{~m}, 1 \mathrm{~F}),-149.00\left(\mathrm{dt}, 1 \mathrm{~F}, J^{\prime}=7.12 \mathrm{~Hz}, J^{\prime \prime}\right.$ $=19.78 \mathrm{~Hz}),-157.79(\mathrm{t}, 1 \mathrm{~F}, J=20.60 \mathrm{~Hz}) .{ }^{11} \mathrm{~B} \mathrm{NMR}\left(128 \mathrm{MHz}, \mathrm{CDCl}_{3}\right): \delta$, ppm 1.26 (br t, 1B). HRMS (ESI-TOF) $\mathrm{m} / z$ [M $+\mathrm{H}]^{+}$calcd for $\mathrm{C}_{42} \mathrm{H}_{27} \mathrm{~B}_{2} \mathrm{~F}_{12} \mathrm{~N}_{6} 863.2359$; found: 863.2341. 
BODIPY 7.-30 $\mathrm{mg}$ of BODIPY $2(0.06 \mathrm{mmol})$ was dissolved in $6 \mathrm{~mL}$ of THF/toluene 1:1 and purged with nitrogen. To the resulting solution, 4-(trifluoromethyl)phenylboronic acid (114 mg, $0.60 \mathrm{mmol})$ and $\mathrm{Pd}\left(\mathrm{PPh}_{3}\right)_{2} \mathrm{Cl}_{2}(8.4 \mathrm{mg}, 0.012 \mathrm{mmol})$ were added. Then, $1.2 \mathrm{~mL}$ of $\mathrm{K}_{2} \mathrm{CO}_{3} 1 \mathrm{M}$ aq. was added, and the mixture was heated at $75^{\circ} \mathrm{C}$ for $4 \mathrm{~h}$. The solvent was removed under reduced pressure, and the residue was chromatographed on a silica gel column using $\mathrm{CH}_{2} \mathrm{Cl}_{2} /$ hexane $4: 6$ as eluent, obtaining $8.3 \mathrm{mg}$ of pure product. Yield $=22 \%$. m.p.: $268-270{ }^{\circ} \mathrm{C}$. UV-vis (THF): $\lambda_{\max }, \mathrm{nm}(\log \varepsilon) 556$ (sh, 4.46), 590 (4.83). ${ }^{1} \mathrm{H}$ NMR (400 MHz, $\left.\mathrm{CDCl}_{3}\right): \delta$, ppm 7.82-7.76 (m, 2H, Ph), 7.74 (s, 1H, CHmeso), 7.73-7.67 (m, $4 \mathrm{H}, \mathrm{Ph}), 7.63$ (d, 2H, $J=8.2 \mathrm{~Hz}, \mathrm{Ph}), 2.36$ (s, 3H, $\left.\mathrm{CH}_{3}\right), 1.94$ (s, 3H, $\left.\mathrm{CH}_{3}\right) .{ }^{13} \mathrm{C}$ NMR $(125$ $\mathrm{MHz}, \mathrm{CDCl}_{3}$ ): $\delta$, ppm 156.4, 140.2, 134.9, 134.3, 133.3, 132.1, 131.8, 131.2, 130.9, 130.5, $130.0,129.9,129.9,127.8,126.0,125.3,125.2,125.1,125.1,125.0,125.0,124.8,124.8$, $124.7,122.7,122.7,122.6,122.5,10.1,9.8 .{ }^{19} \mathrm{~F} \mathrm{NMR}\left(376 \mathrm{MHz}, \mathrm{CDCl}_{3}\right): \delta$, ppm $\delta-62.77$ (s, 3F, $\left.\mathrm{CF}_{3}\right),-62.86\left(\mathrm{~s}, 3 \mathrm{~F}, \mathrm{CF}_{3}\right),-130.55(\mathrm{q}, 2 \mathrm{~F}, J=27.92 \mathrm{~Hz}),-140.86\left(\mathrm{td}, 1 \mathrm{~F}, J^{\prime}=18.84\right.$, $\left.J^{\prime \prime}=4.60 \mathrm{~Hz}\right),-147.37(\mathrm{t}, 1 \mathrm{~F}, J=19.26 \mathrm{~Hz}),-151.24\left(\mathrm{td}, 1 \mathrm{~F}, J^{\prime}=19.00, J^{\prime \prime}=4.60 \mathrm{~Hz}\right)$, $-158.45(\mathrm{t}, 1 \mathrm{~F}, J=18.65 \mathrm{~Hz}) .{ }^{11} \mathrm{~B}$ NMR $\left(128 \mathrm{MHz}, \mathrm{CDCl}_{3}\right): \delta$, ppm 0.99 (t, 1B, $J=30.3$ $\mathrm{Hz})$.

BODIPY 8.-Stille coupling: BODIPY $2(30 \mathrm{mg}, 0.06 \mathrm{mmol})$ was dissolved in $4 \mathrm{~mL}$ of dry toluene and the solution was purged with nitrogen. To this solution, $196 \mu \mathrm{L}$ of tributylphenylstannane $(0.60 \mathrm{mmol})$ and $8.4 \mathrm{mg}$ of $\mathrm{Pd}\left(\mathrm{PPh}_{3}\right)_{2} \mathrm{Cl}_{2}(0.012 \mathrm{mmol})$ were added. The mixture was heated at $100{ }^{\circ} \mathrm{C}$ for $90 \mathrm{~min}$. The solvent was removed under reduced pressure, and the residue was chromatographed on a silica gel column using $\mathrm{CH}_{2} \mathrm{Cl}_{2}$ /hexane $8: 2$ as eluent, obtaining $15.4 \mathrm{mg}$ of pure product. Yield $=52 \%$. Suzuki coupling: BODIPY 2 (30 mg, $0.06 \mathrm{mmol}$ ) was dissolved in $6 \mathrm{~mL}$ of THF/toluene 1:1 and the solution was purged with nitrogen. To this solution, $7.2 \mathrm{mg}$ of phenylboronic acid $(0.60 \mathrm{mmol})$ and $8.4 \mathrm{mg}$ of $\mathrm{Pd}\left(\mathrm{PPh}_{3}\right)_{2} \mathrm{Cl}_{2}(0.012 \mathrm{mmol})$ were added. Then, $1.2 \mathrm{~mL}$ of $\mathrm{K}_{2} \mathrm{CO}_{3} 1 \mathrm{M}$ aq. was added, and the mixture was heated at $75{ }^{\circ} \mathrm{C}$ for $3 \mathrm{~h}$. The solvent was removed under reduced pressure, and the residue was chromatographed on a silica gel column using $\mathrm{CH}_{2} \mathrm{Cl}_{2} /$ hexane $6: 4$ as eluent, obtaining $13.3 \mathrm{mg}$ of pure product. Yield $=45 \%$. m.p.: $254-256{ }^{\circ} \mathrm{C}$. UV-vis (THF): $\lambda_{\max }, \mathrm{nm}(\log \varepsilon) 554$ (sh, 4.49), 589 (4.88). ${ }^{1} \mathrm{H}$ NMR (500 MHz, $\mathrm{CD}_{2} \mathrm{Cl}_{2}$ ): $\delta$, ppm 7.73 (s, $1 \mathrm{H}, \mathrm{CH}$ meso), $7.62(\mathrm{~m}, 2 \mathrm{H}, \mathrm{Ph}), 7.52-7.41(\mathrm{~m}, 8 \mathrm{H}, \mathrm{Ph}), 2.33\left(\mathrm{~s}, 3 \mathrm{H}, \mathrm{CH}_{3}\right), 1.91(\mathrm{~s}, 3 \mathrm{H}$, $\left.\mathrm{CH}_{3}\right) \cdot{ }^{13} \mathrm{C}$ NMR $\left(125 \mathrm{MHz}, \mathrm{CDCl}_{3}\right): \delta$, ppm 158.1, 149.9, 139.9, 134.1, 131.8, 130.4, 130.1, 130.0, 129.9, 129.6, 129.6, 129.6, 129.2, 128.0, 127.9, 127.6, 125.5, 125.5, 125.4, 122.1, $122.1,118.9,118.8,115.6,9.9,9.6 .{ }^{19} \mathrm{~F} \mathrm{NMR}\left(376 \mathrm{MHz}, \mathrm{CDCl}_{3}\right): \delta$, ppm $\delta-130.91(\mathrm{q}, 2 \mathrm{~F}$, $J=38.92 \mathrm{~Hz}),-142.67\left(\mathrm{td}, 1 \mathrm{~F}, J^{\prime}=24.80, J^{\prime \prime}=6.0 \mathrm{~Hz}\right),-148.43(\mathrm{t}, 1 \mathrm{~F}, J=23.31 \mathrm{~Hz})$, $-153.65\left(\mathrm{td}, 1 \mathrm{~F}, J^{\prime}=23.31, J^{\prime \prime}=6.00 \mathrm{~Hz}\right),-160.94(\mathrm{t}, 1 \mathrm{~F}, J=23.31 \mathrm{~Hz}) .{ }^{11} \mathrm{~B}$ NMR $(128$ $\mathrm{MHz}, \mathrm{CDCl}_{3}$ ): $\delta$, ppm 0.99 (t, 1B, $J=38.4 \mathrm{~Hz}$ ). HRMS (ESI-TOF) $\mathrm{m} / z[\mathrm{M}+\mathrm{H}]^{+}$calcd for $\mathrm{C}_{27} \mathrm{H}_{17} \mathrm{BF}_{6} \mathrm{~N}_{2}$ 494.1389; found 494.1383 .

BODIPY 9.-Stille coupling: BODIPY $2(30 \mathrm{mg}, 0.06 \mathrm{mmol})$ was dissolved in $4 \mathrm{~mL}$ of toluene dry and the solution was purged with nitrogen. To this solution, $189 \mu \mathrm{L}$ of 2 (tributylstannyl)furane $(0.60 \mathrm{mmol})$ and $8.4 \mathrm{mg}$ of $\mathrm{Pd}\left(\mathrm{PPh}_{3}\right)_{2} \mathrm{Cl}_{2}(0.012 \mathrm{mmol})$ were added. The mixture was heated at $100{ }^{\circ} \mathrm{C}$ for $1 \mathrm{~h}$. The solvent was removed under reduced pressure, and the residue was chromatographed on a silica gel column using $\mathrm{CH}_{2} \mathrm{Cl}_{2}$ /hexane 8:2 as eluent, obtaining $9.1 \mathrm{mg}$ of pure product. Yield $=32 \%$. Suzuki coupling: BODIPY (30 mg, 
$0.06 \mathrm{mmol}$ ) was dissolved in $6 \mathrm{~mL}$ of THF/toluene 1:1 and the solution was purged with nitrogen. To this solution, $67.2 \mathrm{mg}$ of 2-furanylboronic acid $(0.60 \mathrm{mmol})$ and $8.4 \mathrm{mg}$ of $\mathrm{Pd}\left(\mathrm{PPh}_{3}\right)_{2} \mathrm{Cl}_{2}(0.012 \mathrm{mmol})$ were added. Then, $1.2 \mathrm{~mL}$ of $\mathrm{K}_{2} \mathrm{CO}_{3} 1 \mathrm{M}$ aq. was added, and the mixture was heated at $75^{\circ} \mathrm{C}$ for $2 \mathrm{~h}$. The solvent was removed under reduced pressure, and the residue was chromatographed on a silica gel column using $\mathrm{CH}_{2} \mathrm{Cl}_{2} /$ hexane $6: 4$ as eluent, obtaining $6.3 \mathrm{mg}$ of pure product. Yield $=22 \%$. m.p.: $275-276{ }^{\circ} \mathrm{C}$. UV-vis (THF): $\lambda_{\max }, \mathrm{nm}(\log \varepsilon) 625$ (sh, 4.52), 669 (4.85). ${ }^{1} \mathrm{H}$ NMR (500 MHz, $\left.\mathrm{CDCl}_{3}\right): \delta, \mathrm{ppm} 7.75(\mathrm{~d}$, $1 \mathrm{H}, J=1.8 \mathrm{~Hz}), 7.67(\mathrm{~d}, 1 \mathrm{H}, J=1.7 \mathrm{~Hz}), 7.63\left(\mathrm{dd}, 2 \mathrm{H}, J^{\prime}=7.0, J^{\prime \prime}=3.7 \mathrm{~Hz}\right), 7.46(\mathrm{~s}, 1 \mathrm{H}$, $\mathrm{CH}$ meso $), 6.70\left(\mathrm{dd}, 1 \mathrm{H}, J^{\prime}=3.6, J^{\prime \prime}=1.7 \mathrm{~Hz}\right), 6.65\left(\mathrm{dd}, 1 \mathrm{H}, J^{\prime}=3.7, J^{\prime \prime}=1.7 \mathrm{~Hz}, 1 \mathrm{H}\right)$, 2.29 (s, 3H, $\left.\mathrm{CH}_{3}\right), 2.24$ (s, $\left.3 \mathrm{H}, \mathrm{CH}_{3}\right) .{ }^{13} \mathrm{C} \mathrm{NMR}\left(125 \mathrm{MHz}, \mathrm{CDCl}_{3}\right): \delta$, ppm 146.9, 145.6, 145.1, 144.9, 143.9, 139.3, 139.2, 137.1, 135.5, 128.5, 126.2, 118.6, 118.0, 117.9, 117.9, $117.2,117.1,117.1,112.9,112.9,29.7,11.4,9.7 .{ }^{19} \mathrm{~F} \mathrm{NMR}\left(376 \mathrm{MHz}, \mathrm{CDCl}_{3}\right): \delta$, ppm $\delta$ $-135.72\left(\mathrm{td}, 1 \mathrm{~F}, J^{\prime}=18.60, J^{\prime \prime}=4.96 \mathrm{~Hz}\right),-139.96(\mathrm{q}, 2 \mathrm{~F}, J=31.42 \mathrm{~Hz}),-148.61(\mathrm{t}, 1 \mathrm{~F}, J$ $=19.35 \mathrm{~Hz}),-153.30\left(\mathrm{td}, \mathrm{IF}, J^{\prime}=19.28, J^{\prime \prime}=4.88 \mathrm{~Hz}\right),-159.13(\mathrm{t}, 1 \mathrm{~F}, J=18.62 \mathrm{~Hz}) .{ }^{11} \mathrm{~B}$ NMR (128 MHz, $\mathrm{CDCl}_{3}$ ): $\delta$, ppm 1.53 (t, 1B, $J=31.7 \mathrm{~Hz}$ ). HRMS (ESI-TOF) $m / z$ [M + H] ${ }^{+}$calcd for $\mathrm{C}_{23} \mathrm{H}_{13} \mathrm{BF}_{6} \mathrm{~N}_{2} \mathrm{O}_{2}$ 474.1053; found 474.1083.

\section{Supplementary Material}

Refer to Web version on PubMed Central for supplementary material.

\section{ACKNOWLEDGMENTS}

This work was supported by the U.S. National Institutes of Health (R01 CA179902) and the National Science Foundation (CHE 1362641). The authors thankfully acknowledge the Tor Vergata Scuola di Dottorato support for study abroad.

\section{REFERENCES}

(1). (a)Loudet A; Burgess K BODIPY Dyes and Their Derivatives: Syntheses and Spectroscopic Properties. Chem. Rev 2007, 107, 4891-4932. [PubMed: 17924696] (b)Ulrich G; Ziessel R; Harriman A The Chemistry of Fluorescent Bodipy Dyes: Versatility Unsurpassed. Angew. Chem., Int. Ed 2008, 47, 1184-1201.(c)Lu H; Mack J; Yang Y; Shen Z Structural Modification Strategies for the Rational Design of Red/NIR Region BODIPYs. Chem. Soc. Rev 2014, 43, 4778-4823. [PubMed: 24733589] (d)Ge Y; O’Shea DF Azadipyrromethenes: From Traditional Dye Chemistry to Leading Edge Applications. Chem. Soc. Rev 2016, 45, 3846-3864. [PubMed: 27181703]

(2). (a)Hendricks JA; Keliher EJ; Wan D; Hilderbrand SA; Weissleder R; Mazitschek R Synthesis of [18F]BODIPY: Bifunctional Reporter for Hybrid Optical/Positron Emission Tomography Imaging. Angew. Chem., Int. Ed 2012, 51, 4603-4606.(b)Zeng L; Miller EW; Pralle A; Isacoff EY; Chang CJ A Selective Turn-On Fluorescent Sensor for Imaging Copper in Living Cells. J. Am. Chem. Soc 2006, 128, 10-11. [PubMed: 16390096] (c)Devaraj NK; Hilderbrand S; Upadhyay R; Mazitschek R; Weissleder R Bioorthogonal Turn-On Probes for Imaging Small Molecules inside Living Cells. Angew. Chem., Int. Ed 2010, 49, 2869-2872.(d)Martin A; Byrne A; Dolan C; Forster RJ; Keyes TE Solvent Switchable Dual Emission from a Bichromophoric Ruthenium-BODIPY Complex. Chem. Commun 2015, 51, 15839-15841.(e)Li Z; Bittman R Synthesis and Spectral Properties of Cholesterol- and FTY720-containing Boron Dipyrromethene Dyes. J. Org. Chem 2007, 72, 8376-8382. [PubMed: 17914846]

(3). (a)Rousseau T; Cravino A; Bura T; Ulrich G; Ziessel R; Roncali J BODIPY Derivatives as Donor Materials for Bulk Heterojunction Solar Cells. Chem. Commun 2009, 1673-1675.(b)Loudet A; Bandichhor R; Wu L; Burgess K Functionalized BF2 Chelated Azadipyrromethene Dyes. Tetrahedron 2008, 64, 3642-3654. [PubMed: 19458781] (c)Coskun A; Deniz E; Akkaya EU 
Effective PET and ICT Switching of Boradiazaindacene Emission: A Unimolecular, EmissionMode, Molecular Half-Subtractor with Reconfigurable Logic Gates. Org. Lett 2005, 7, 5187 5189. [PubMed: 16268534] (d)Boens N; Leen V; Dehaen W Fluorescent Indicators Based on BODIPY. Chem. Soc. Rev 2012, 41, 1130-1172. [PubMed: 21796324] (e)Kowada T; Maeda H; Kikuchi K BODIPY-based Probes for the Fluorescence Imaging of Biomolecules in Living Cells. Chem. Soc. Rev 2015, 44, 4953-4972. [PubMed: 25801415]

(4). (a)Wang F; Zhou L; Zhao C; Wang R; Fei Q; Luo S; Guo Z; Tian H; Zhu W-H A Dual-response BODIPY-based Fluorescent Probe for the Discrimination of Glutathione from Cystein and Homocystein. Chem. Sci 2015, 6, 2584-2589. [PubMed: 29560246] (b)Keum D; Kim S; Kim Y A Fluorescence Turn-on Sensor for the Detection of Palladium Ions that Operates Through in situ Generation of Palladium Nanoparticles. Chem. Commun 2014, 50, 1268-1270.(c)Yuan M; Zhou W; Liu X; Zhu M; Li J; Yin X; Zheng H; Zuo Z; Ouyang C; Liu H; Li Y; Zhu D A Multianalyte Chemosensor on a Single Molecule: Promising Structure for an Integrated Logic Gate. J. Org. Chem 2008, 73, 5008-5014. [PubMed: 18522421] (d)Hudnall TW; Gabbai FP A BODIPY Boronium Cation for the Sensing of Fluoride Ions. Chem. Commun 2008, 4596-4597.

(5). (a)Yogo T; Urano Y; Ishitsuka Y; Maniwa F; Nagano T Highly Efficient and Photostable Photosensitizer Based on BODIPY Chromophore. J. Am. Chem. Soc 2005, 127, 12162-12163. [PubMed: 16131160] (b)Kamkaew A; Burgess K Double-Targeting Using a TrkC Ligand Conjugated to Dipyrrometheneboron Difluoride (BODIPY) Based Photodynamic Therapy (PDT) Agent. J. Med. Chem 2013, 56, 7608-7614. [PubMed: 24063347] (c)Kamkaew A; Lim SH; Lee HB; Kiew LV; Chung LY; Burgess K BODIPY Dyes in Photodynamic Therapy. Chem. Soc. Rev 2013, 42, 77-88. [PubMed: 23014776] (d)Gibbs JH; Zhou Z; Kessel D; Fronczek FR; Pakhomova S; Vicente MGH Synthesis, Spectroscopic, and in vitro Investigations of 2,6-DiiodoBODIPYs with PDT and Multi-mode Imaging Applications. J. Photochem. PhotobioL, B 2015, 145, 35-47. [PubMed: 25771382] (e)Neelakandan PP; Jimenez A; Thoburn JD; Nitschke J R An Autocatalytic System of Photooxidation-driven Substitution Reactions on a FeII4L6 Cage Framework. Angew. Chem., Int. Ed 2015, 54, 14378-14382.

(6). (a)Baruah M; Qin W; Basaric N; De Borggraeve WM; Boens N BODIPY-Based Hydroxyaryl Derivatives as Fluorescent pH Probes. J. Org. Chem 2005, 70, 4152-4157. [PubMed: 15876108] (b)Rohand T; Qin W; Boens N; Dehaen W Palladium-catalyzed Coupling Reactions for the Functionalization of BODIPY Dyes with Fluorescence Spanning the Visible Spectrum. Eur. J. Org. Chem 2006, 2006, 4658-4663.(c)Duran-Sampedro G; Agarrabeitia AR; Garcia-Moreno I; Costela A; Banuelos J; Arbeloa T; Lop ez Arbeloa I; Chiara JL; Ortiz MJ Chlorinated BODIPYs: Surprisingly Efficient and Highly Photostable Laser Dyes. Eur. J. Org. Chem 2012, 2012, 63356350.(d)Zhao N; Xuan S; Fronczek FR; Smith KM; Vicente MG Stepwise Polychlorination of 8chloro-BODIPY and Regioselective Functionalization of 2,3,5,6,8-pentachloro-BODIPY. J. Org. Chem 2015, 80, 8377-8383. [PubMed: 26186141] (e)Xuan S; Zhao N; Ke X; Zhou Z; Fronczek FR; Kadish KM; Smith KM; Vicente MGH Synthesis and Spectroscopic Investigation of a Series of Push-Pull Boron Dipyrromethenes (BODIPYs). J. Org. Chem 2017, 82, 2545-2557. [PubMed: 28150499]

(7). (a)Hayashi Y; Yamaguchi S; Cha WY; Kim D; Shinokubo, Synthesis of Directly Connected BODIPY Oligomers Through Suzuki-Miyaura Coupling. Org. Lett 2011, 13, 2992-2995. [PubMed: 21591621] (b)Lakshmi V; Ravikanth M Synthesis of Sterically Crowded Polyarylated Boron-Dipyrromethenes. J. Org. Chem 2011, 76, 8466-8471. [PubMed: 21910483] (c)Lai Y-C; Su S-Y; Chang CC Special Reactive Oxygen Species Generation by a Highly Photostable BODIPY-Based Photosensitizer for Selective Photodynamic Therapy. ACSAppl. Mater. Interfaces 2013, 5, 12935-12943.(d)Jiao L; Pang W; Zhou J; Wei Y; Mu X; Bai G; Hao E Regioselective Stepwise Bromination of Boron Dipyrromethene (BODIPY) Dyes. J. Org. Chem 2011, 76, 9988-9996. [PubMed: 22077955] (e)Lakhe D; Jairaj KK; Pradhan M; Ladiwala U; Agarwal N Synthesis and Photophysical Studies of Heteroaryl Substituted BODIPY Derivatives for Biological Applications. Tetrahedron Lett 2014, 55, 7124-7129.

(8). (a)Jiao L; Yu C; Uppal T; Liu M; Li Y; Zhou Y; Hao E; Hu X; Vicente MGH Long Wavelength Red Fluorescent Dyes from 3,5-Diiodo-BODIPYs. Org. Biomol Chem 2010, 8, 2517-2519. [PubMed: 20390194] (b)Ye JH; Hu Z; Wang Y; Zhang W; Zhang Y A New Practical and Highly Efficient Iodination of BODIPY Derivatives with Hypervalent Iodine Reagent. Tetrahedron Lett 2012, 53, 6858-6860.(c)Ortiz MJ; Agarrabeitia AR; Duran-Sampedro G; Prieto JB; Lopez TA; 
Massad WA; Montejano HA; García NA; Arbeloa IL Synthesis and Functionalization of New Polyhalogenated BODIPY Dyes. Study of Their Photophysical Properties and Singlet Oxygen Generation. Tetrahedron 2012, 68, 1153-1162.(d)Meng Q; Fronczek FR; Vicente MGH Synthesis and Spectroscopic Properties of $\beta, \beta$ 'Dibenzo-3,5,8-triaryl-BODIPYs. New J. Chem 2016, 40, 5740-5751.

(9). (a)Rohand T; Baruah M; Qin W; Boens N; Dehaen W Functionalisation of Fluorescent BODIPY Dyes by Nucleophilic Substitution. Chem. Commun 2006, 266-268.(b)Leen V; Leemans T; Boens N; Dehaen W 2- and 3-Monohalogenated BODIPY Dyes and Their Functionalized Analogues: Synthesis and Spectroscopy. Eur. J. Org. Chem 2011, 2011, 4386-4396.(c)Li L; Nguyen B; Burgess K Functionalization of the 4,4-Difluoro-4-bora-3a,4a-diaza-s-indacene (BODIPY) core. Bioorg. Med. Chem. Lett 2008, 18, 3112-3116. [PubMed: 18037291] (d)Jiang T; Zhang P; Yu C; Yin J; Jiao L; Dai E; Wang J; Wei Y; Mu X; Hao E Straightforward Synthesis of Oligopyrroles through a Regioselective SNAr Reaction of Pyrroles and Halogenated Boron Dipyrrins. Org. Lett 2014, 16, 1952-1955. [PubMed: 24670106] (e)Zhao N; Vicente MGH; Fronczek FR; Smith KM Synthesis of 3,8-Dichloro-6-ethyl-1,2,5,7-tetramethyl-BODIPY from an Asymmetric Dipyrroketone and Reactivity Studies at the 3,8,5-positions. Chem. - Eur. J 2015, 21, 6181-6192. [PubMed: 25761150]

(10). (a)Leen V; Braeken E; Luckermans K; Jackers C; Van der Auweraer M; Boens N; Dehaen W A Versatile, Modular Synthesis of Monofunctionalized BODIPY Dyes. Chem. Commun 2009, 4515-4517.(b)Han J; Gonzalez O; Aguilar-Aguilar A; Pena-Cabrera E; Burgess K 3- and 5Functionalized BODIPYs via the Liebeskind-Srogl Reaction. Org. Biomol. Chem 2009, 7, 34 36. [PubMed: 19081940] (c)Wang H; Fronczek FR; Vicente MGH; Smith KM Synthesis and Functionalization of 3,5,8-Trichlorinated BODIPY Dyes. J. Org. Chem 2014, 79, 10342-10352. [PubMed: 25268574]

(11). Zhao N; Xuan S; Zhou Z; Fronczek FR; Smith KM; Vicente MGH Synthesis, Spectroscopic and Cellular Properties of Near-IR [a]-Phenanthrene-fused BODIPYs. J. Org. Chem 2017, 82, 9744 9750. [PubMed: 28845980]

(12). Uppal T; Hu X; Fronczek FR; Maschek S; Bobadova-Parvanova P; Vicente MGH Synthesis, Computational Modelling and Properties of Benzo-appended BODIPYs. Chem. - Eur. J 2012, 18, 3893-3905. [PubMed: 22367756]

(13). (a)Shen Z; Rohr H; Rurack K; Uno H; Spieles M; Schulz B; Reck G; Ono N Borondiindomethene (BDI) Dyes and Their Tetrahydrobicyclo Precursors - en route to a New Class of Highly Emissive Fluorophores for the Red Spectral Range. Chem. - Eur. J 2004, 10, 4853-4871. [PubMed: 15372665] (b)Wada M; Ito S; Uno H; Murashima T; Ono N; Urano T; Urano Y Synthesis and Optical Properties of a New Class of Pyrromethene-BF2 Complexes Fused with Rigid Bicyclo Rings and Benzo Derivatives. Tetrahedron Lett 2001, 42, 6711-6713.(c)Tomimori Y; Okujima T; Yano T; Mori S; Ono N; Yamada H; Uno H Synthesis of $\pi$-expanded O-chelated Boron-dipyrrome-thene as an NIR Dye. Tetrahedron 2011, 67, 3187-3193.

(14). (a)Yu C; Jiao L; Tan X; Wang J; Xu Y; Wu Y; Yang G; Wang Z; Hao E Straightforward AcidCatalyzed Synthesis of Pyrrolyldipyrromethenes. Angew. Chem., Int. Ed 2012, 51, 7688-7691. (b)Yu C; Xu Y; Jiao L; Zhou J; Wang Z; Hao E Isoindole-BODIPY Dyes as Red to Near-Infrared Fluorophores. Chem. Eur. J 2012, 18, 6437-6442. [PubMed: 22517763] (c)Yu C; Wu Q; Wang J; Wei Y; Hao E; Jiao L Red to Near-Infrared Isoindole BODIPY Fluorophores: Synthesis, Crystal Structures, and Spectroscopic and Electrochemical Properties. J. Org. Chem 2016, 81, 37613770. [PubMed: 27031115]

(15). Uno H; Masuda G; Tukiji M; Nishioka Y; Iida T Novel Preparation of Fluorinated Isoindoles and their Conversion to Fluorinated Benzoporphyrins. Tetrahedron Lett 2007, 48, 7512-7515.

(16). Bhupathiraju NVSDK; Rizvi W; Batteas JD; Drain CM Fluorinated Porphyrinoids as Efficient Platforms for New Photonic Materials, Sensors, and Therapeutics. Org. Biomol. Chem 2016, 14, 389-408. [PubMed: 26514229]

(17). Wu L; Burgess K A New Synthesis of Symmetric Boraindacene (BODIPY) dyes. Chem. Commun 2008, 4933-4935.

(18). (a)Aggarwal A; Singh S; Zhang Y; Anthes M; Samaroo D; Gao R; Drain CM Synthesis and Photophysics of an Octathioglycosylated Zinc(II) Phthalocyanine. Tetrahedron Lett 2011, 52, 5456-5459. [PubMed: 21966031] (b)Pereira JB; Carvalho EFA; Faustino MAF; Fernandes R; Neves MGPMS; Cavaleiro JAS; Gomes NCM; Cunha A; Almeida A; Tome JPC Phthalocyanine 
Thio-pyridinium Derivatives as Antibacterial Photo-sensitizers. Photochem. Photobiol 2012, 88, 537-547. [PubMed: 22332603] (c)Lourenco LMO; Pereira PMR; Maciel E; Valega M; Domingues FMJ; Domingues MRM; Neves MGPMS; Cavaleiro JAS; Fernandes R; Tome JPC Amphiphilic Phthalocyanine-cyclo-dextrin Conjugates for Cancer Photodynamic Therapy. Chem. Commun 2014, 50, 8363-8366.

(19). (a)Yang J-P; Yin H-J; Jia J-J; Wei Y Facile Synthesis of High-Concentration, Stable Aqueous Dispersions of Uniform Silver Nanoparticles using Aniline as a Reductant. Langmuir 2011, 27, 5047-5053. [PubMed: 21434661] (b)Guo Z; Zhang Y; Huang L; Wang M; Wang J; Sun J; Xu L; Gu N One-step Controlled Synthesis of Anisotropic Gold Nanostructures with Aniline as the Reductant in Aqueous Solution. J. Colloid Interface Sci 2007, 309, 518-523. [PubMed: 17300797] (c)Song J; Chu Y; Liu Y; Li L; Sun W Room-temperature Controllable Fabrication of Silver Nanoplates Reduced by Aniline. Chem. Commun 2008, 1223-1225.

(20). Broring M; Kruger R; Link S; Kleeberg C; Kohler S; Xie X; Ventura B; Flamigni L Bis(BF2)-2,2' -bidipyrrins (BisBODIYs): Highly Fluorescent BODIPY Dimers with Large Stokes Shifts. Chem. - Eur. J 2008, 14, 2976-2983. [PubMed: 18306269]

(21). Qin W; Leen V; Rohand T; Dehaen W; Dedecker P; Van der Auweraer M; Robeyns K; Van Meervelt L; Beljonne D; Van Averbeke B; Clifford JN; Driesen K; Binnemans K; Boens N Synthesis, Spectroscopy, Crystal Structure, Electrochemistry, and Quantum Chemical and Molecular Dynamics Calculations of a 3-Anilino Difluoroboron Dipyrromethene dye. J. Phys. Chem. A 2009, 113, 439-447. [PubMed: 19099456]

(22). (a)Ortiz MJ; Agarrabeitia AR; Duran-Sampedro G; Prieto JB; Lopez TA; Massad WA; Montejano HA; Garcia NA; Arbeloa IL Synthesis and Functionalization of New Polyhalogenated BODIPY Dyes. Study of Their Photophysical Properties and Singlet Oxygen Generation. Tetrahedron 2012, 68, 1153-1162.(b)Lim SH; Thivierge C; Nowak-Sliwinska P; Han JY; van den Bergh H; Wagnieres G; Burgess K; Lee HB In Vitro and In Vivo Photocytotoxicity of Boron Dipyrromethene Derivatives for Photodynamic Therapy. J. Med. Chem 2010, 53, 2865-2874. [PubMed: 20199028]

(23). (a)Lakshmi V; Ravikanth M Brominated Boron Dipyrrins: Synthesis, Structure, Spectral and Electrochemical Properties. Dalton Trans 2012, 41, 5903-5911. [PubMed: 22460271] (b)Wang J; Hou Y; Lei W; Zhou Q; Li C; Zhang B; Wang X DNA Photocleavage by a Cationic BODIPY Dye Through Both Singlet Oxygen and Hydroxyl Radical: New Insight Into the Photodynamic Mechanism of BODIPYs. ChemPhysChem 2012, 13, 2739-2747. [PubMed: 22619214]

(24). Olmsted J Calorimetric Determinations of Absolute Fluorescence Quantum Yields. J. Phys. Chem 1979, 83, 2581-2584.

(25). Kancharla P; Reynolds KA Synthesis of 2,2'-Bipyrrole-5-carboxaldehydes and Their Application in the Synthesis of B-ring Functionalized Prodiginines and Tambjamines. Tetrahedron 2013, 69, 8375-8385. 


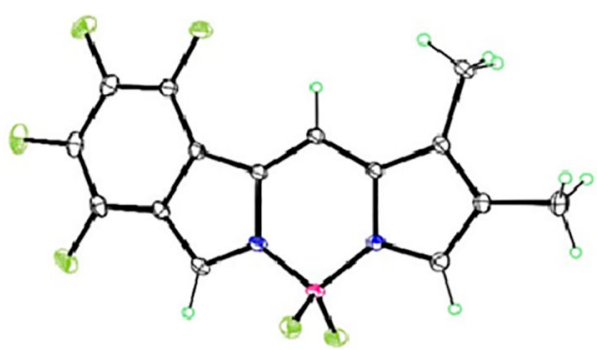

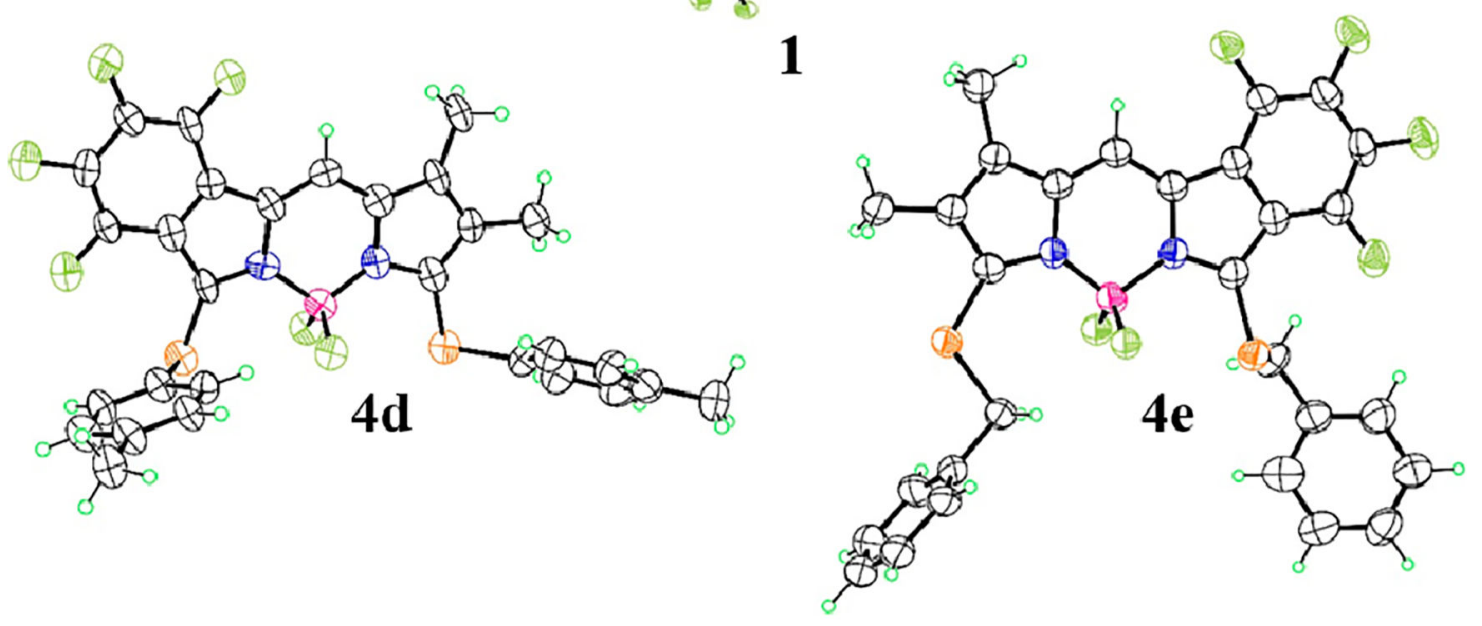

Figure 1.

Molecular structures of BODIPYs 1, 4d, and 4e with $50 \%$ ellipsoids. 


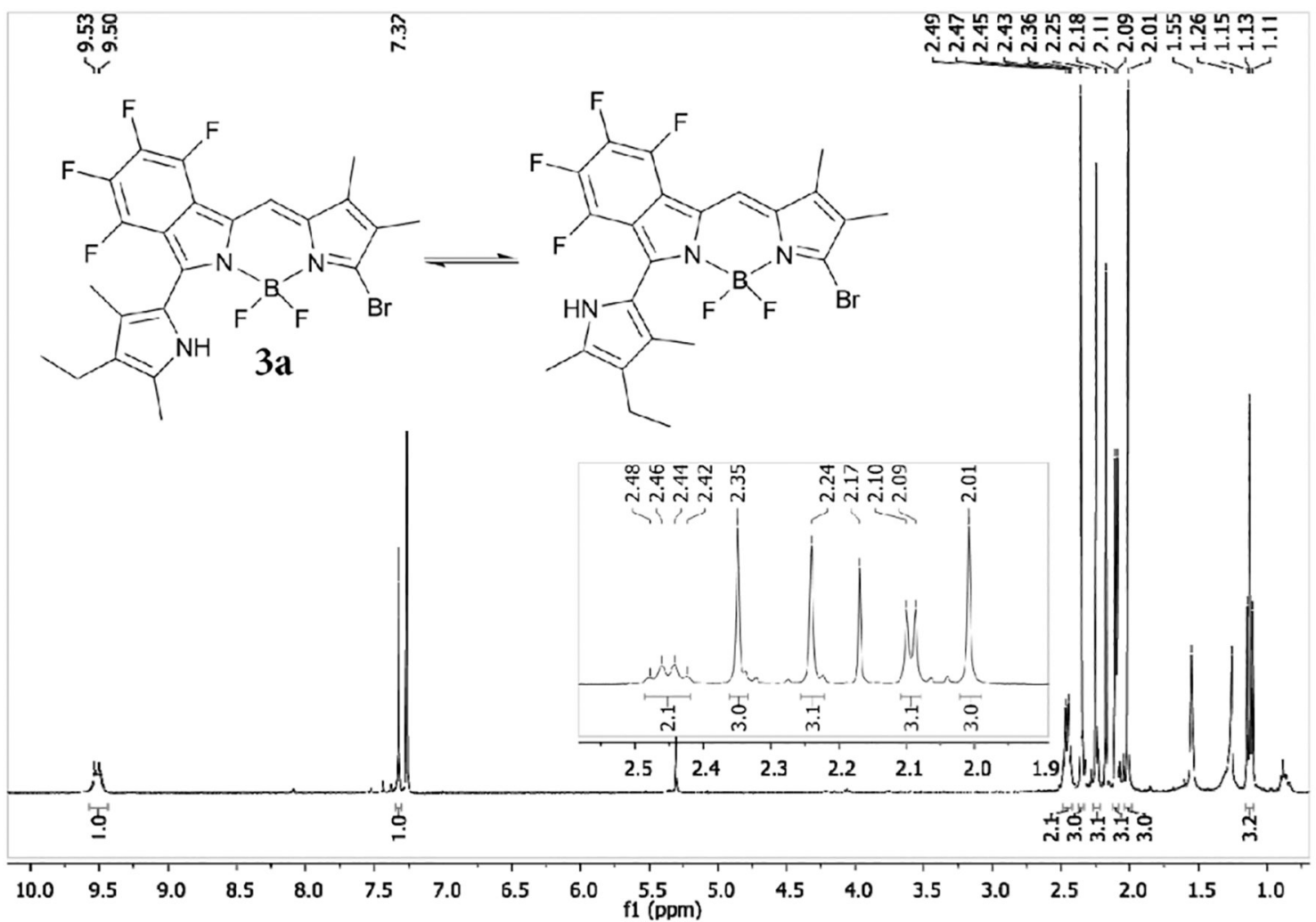

Figure 2.

${ }^{1} \mathrm{H}$ NMR spectrum of compound $\mathbf{3 a}$ in $\mathrm{CDCl}_{3}$. 


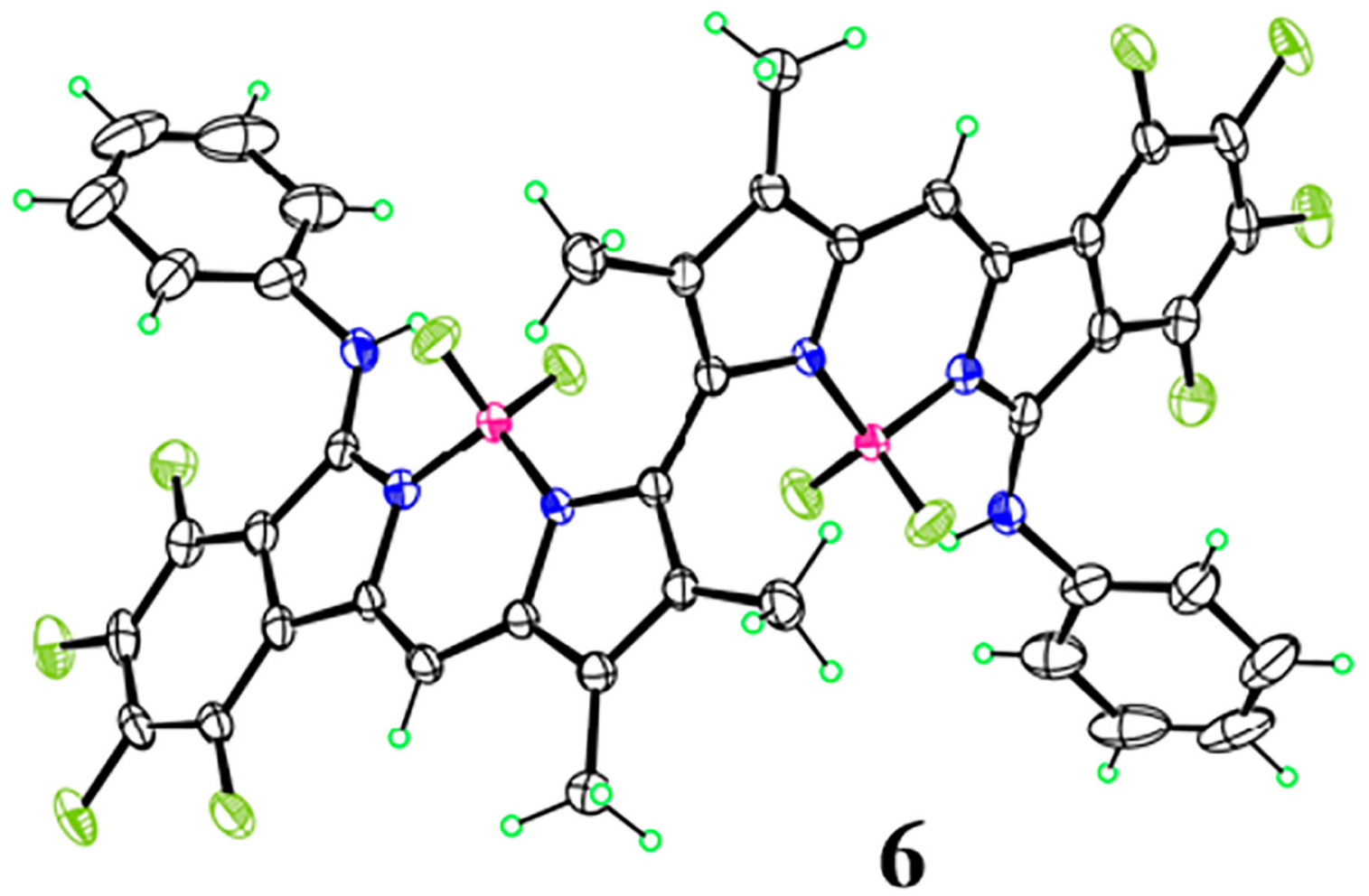

Figure 3.

Molecular structure of dimer 6 with $50 \%$ ellipsoids. 


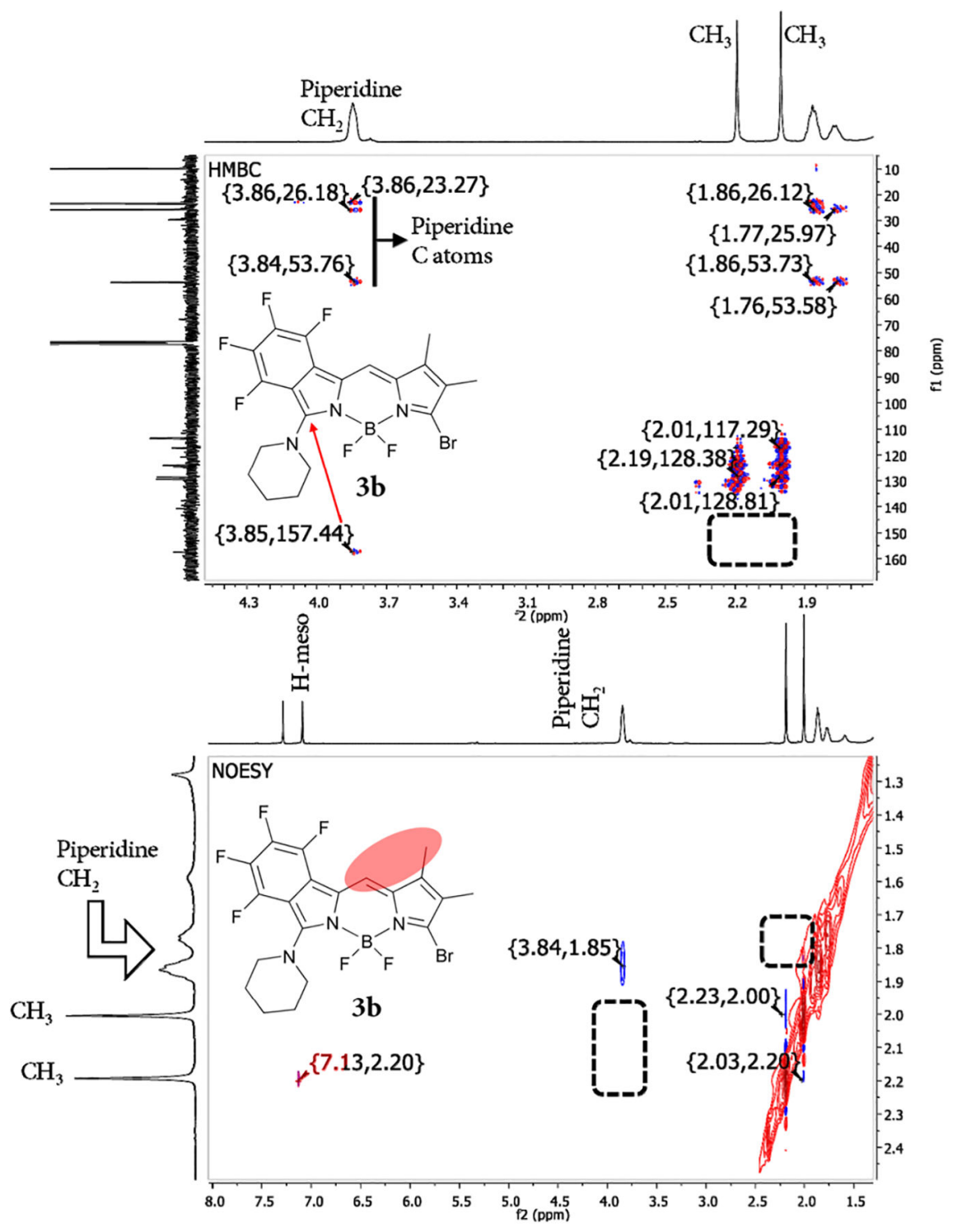

Figure 4.

HMBC and NOESY spectra for BODIPY $\mathbf{3 b}$ in $\mathrm{CDCl}_{3}$. 


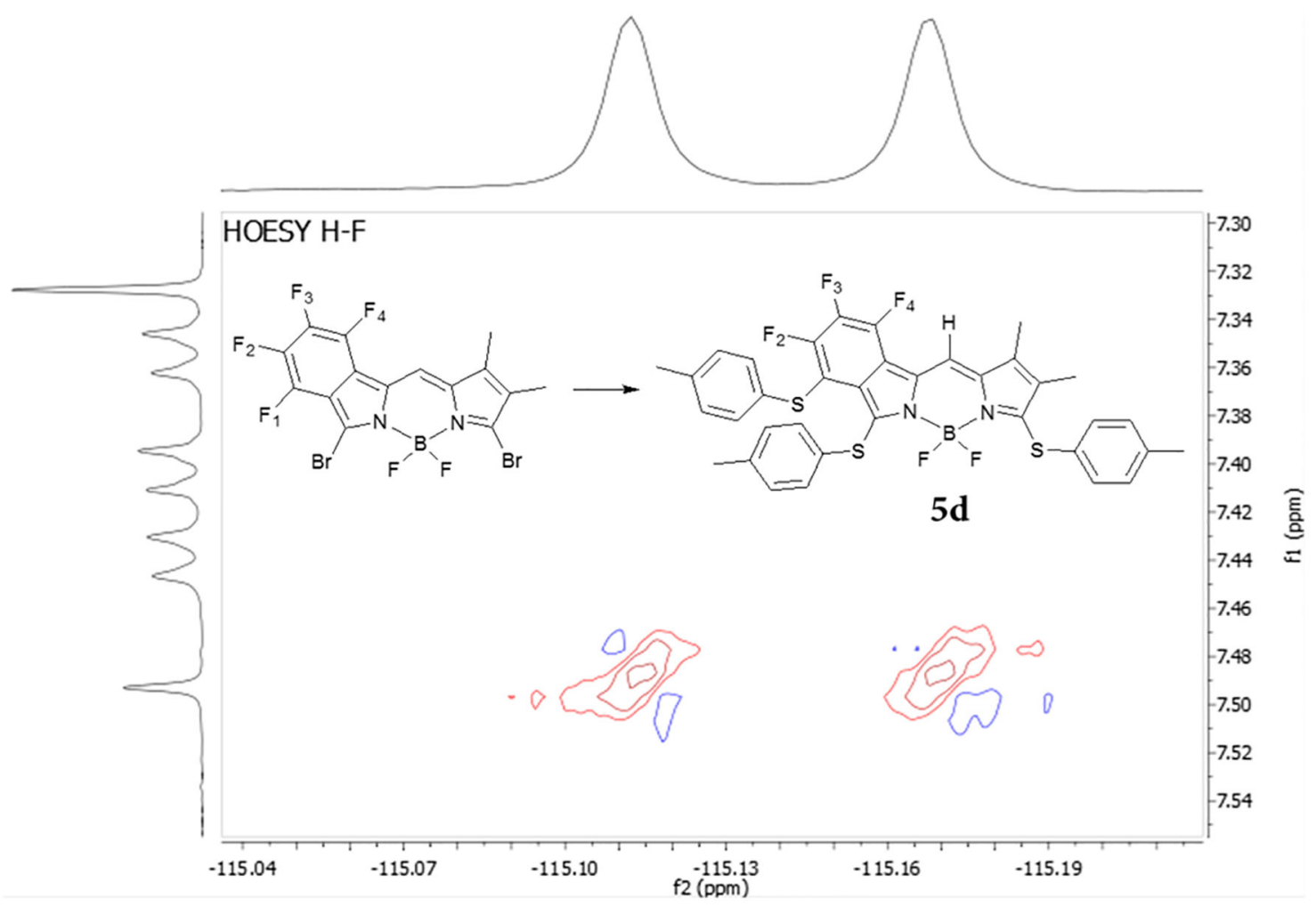

Figure 5.

${ }^{1} \mathrm{H}-{ }^{19} \mathrm{~F}$ HOESY spectrum for compound $\mathbf{5 d}$ in $\mathrm{CDCl}_{3}$. 


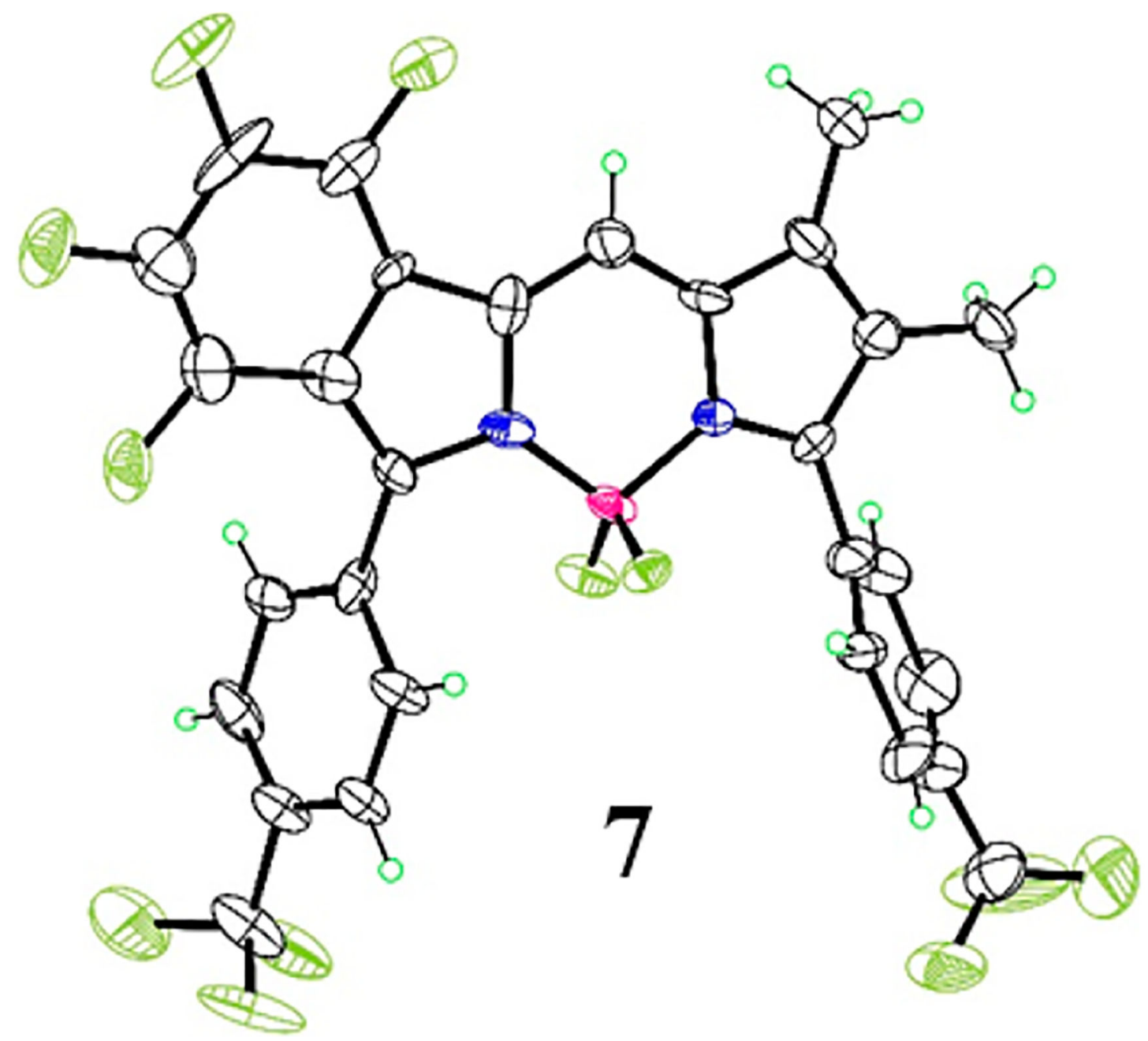

Figure 6.

Molecular structure of BODIPY 7 with 50\% ellipsoids. Only one of the three independent molecules is shown. 

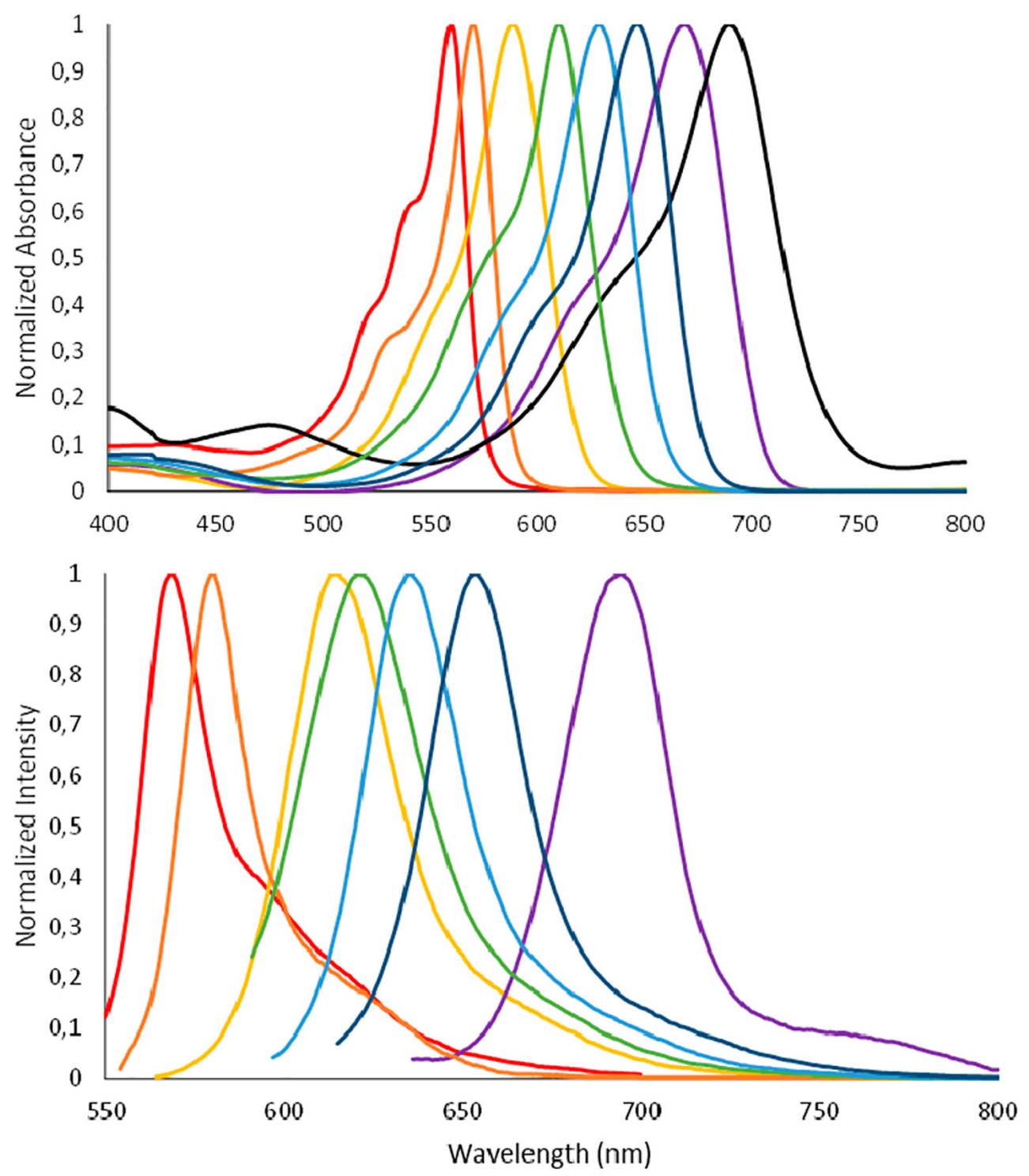

Figure 7.

Normalized UV-vis absorption (top) and emission (bottom) spectra in THF for BODIPYs 1 (red), 3c (orange), 4a (black), 4d (light blue), 4e (green), 5d (blue), 8 (yellow), and 9 (purple). 

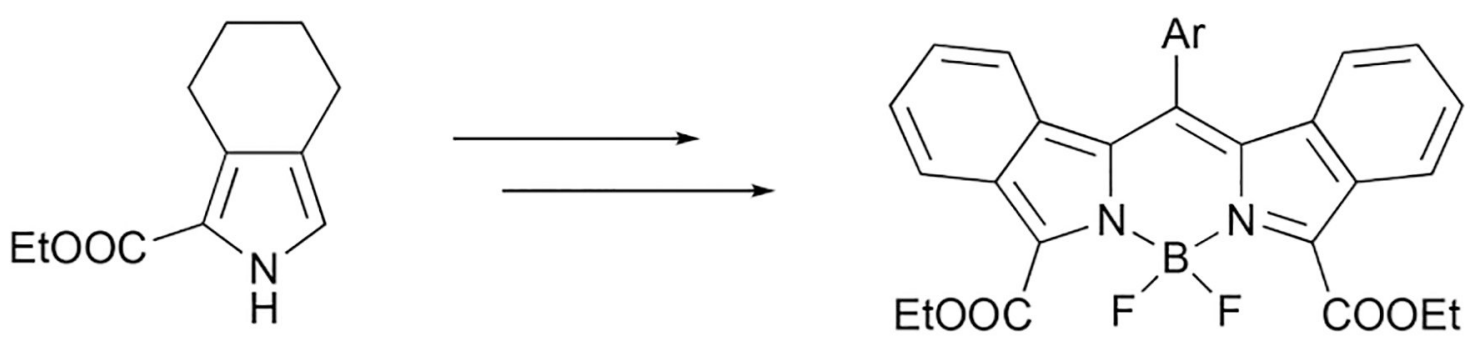<smiles>[R]c1[nH]cc2c1C1C=CC2CC1</smiles>
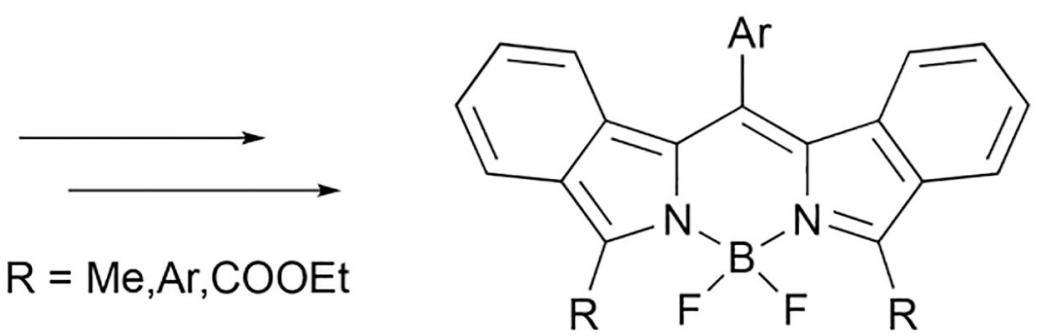<smiles>[R1]C(=O)c1[nH]c(Cl)c2ccccc12</smiles>
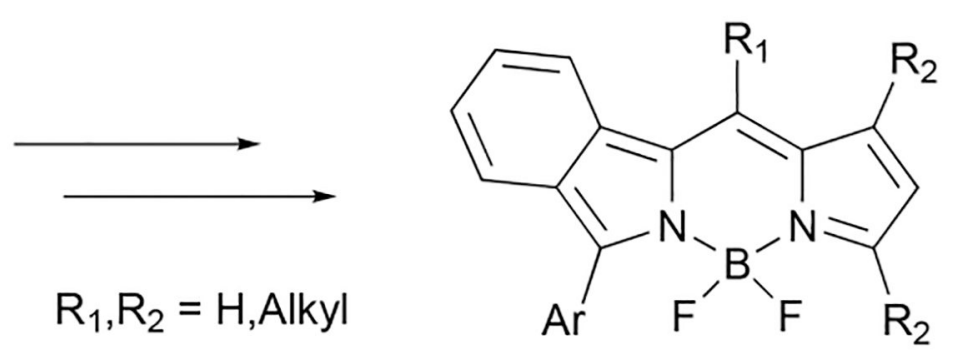

Scheme 1.

Pathways Reported in the Literature for the Synthesis of Benzo-Fused BODIPYs 

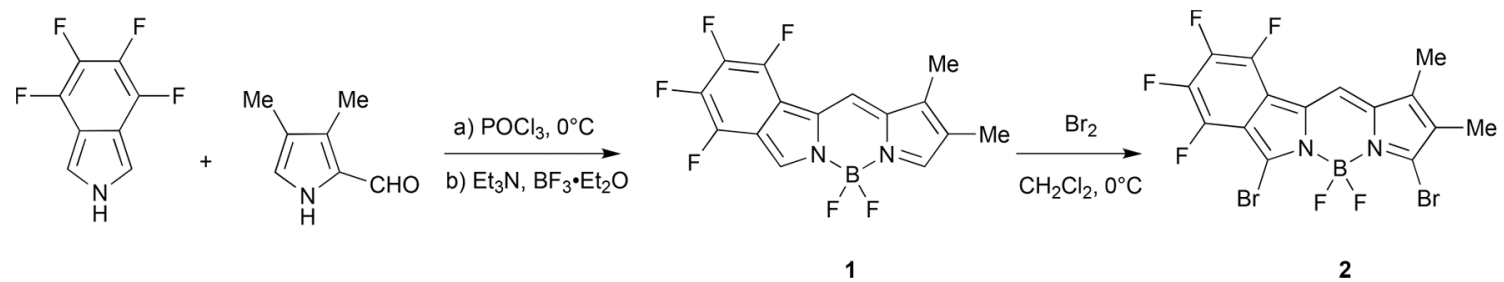

Scheme 2.
Synthesis of BODIPYs 1 and 2

Scheme 2.
Synthesis of BODIPYs 1 and 2 


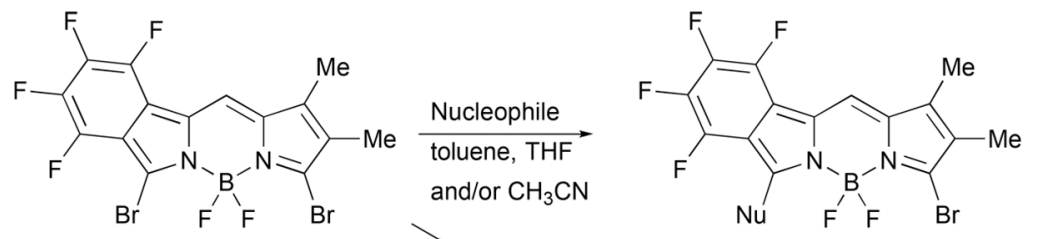

3a, 3b, 3c

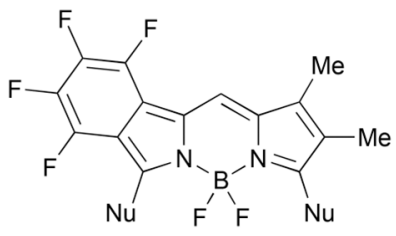

$4 a, 4 d, 4 e$

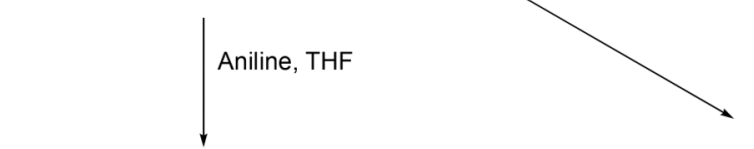<smiles></smiles><smiles>CNc1ccccc1</smiles>

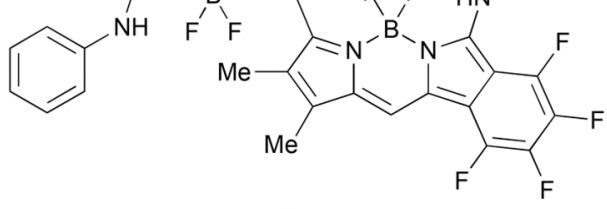

6
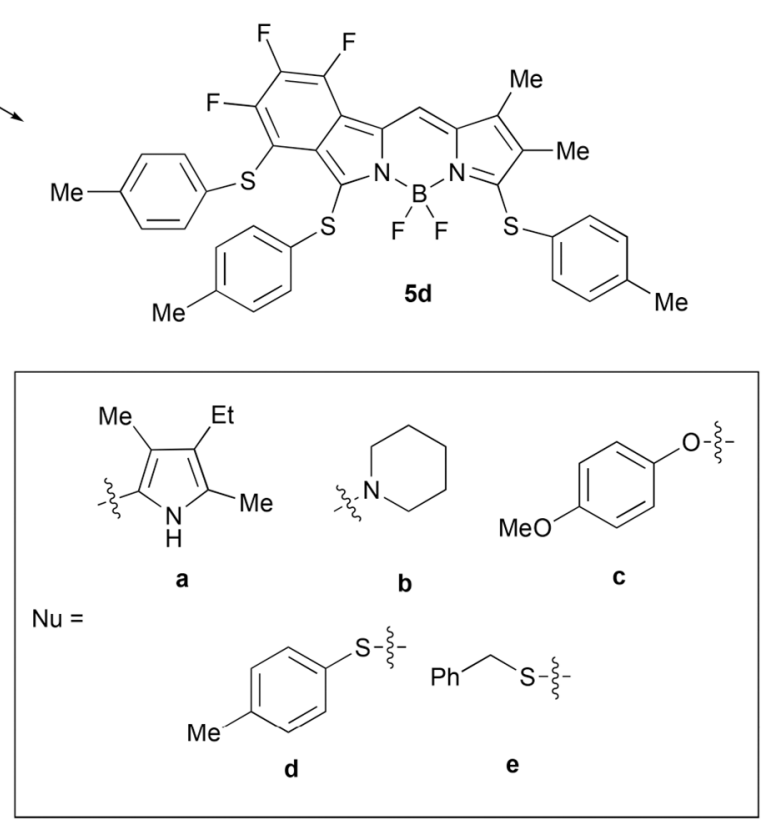

Scheme 3.

Nucleophilic Substitution Reactions of BODIPY 2 


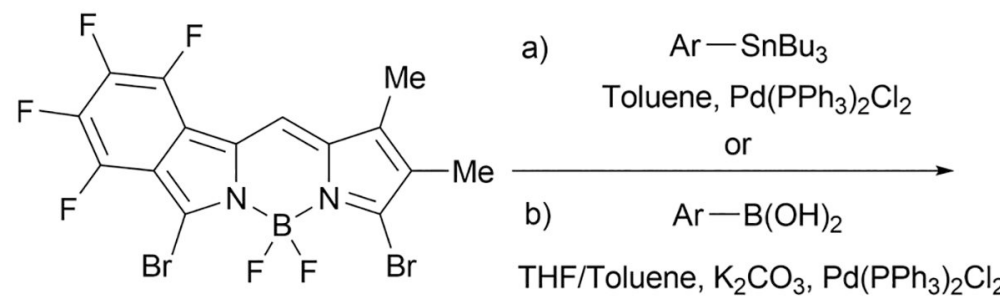

2

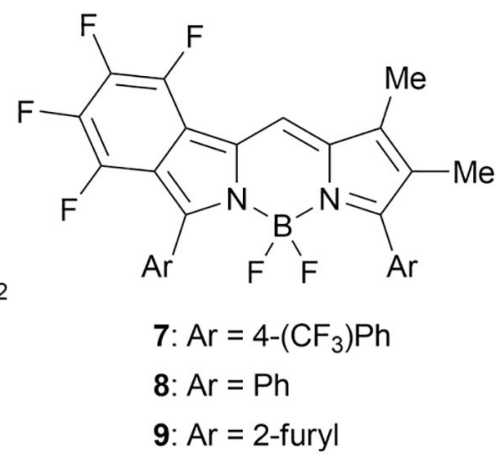

Scheme 4.

Stille (a) and Suzuki (b) Cross-Coupling Reactions of BODIPY 2 
Table 1.

Spectral Properties of the BODIPY Dyes in THF at r.t.

\begin{tabular}{clcccc}
\hline $\mathbf{c m p d}$ & $\mathbf{A b s} \boldsymbol{\lambda}_{\max }(\mathbf{n m})$ & $\boldsymbol{\varepsilon}\left(\mathbf{M}^{\mathbf{- 1}} \mathbf{c m}^{-\mathbf{1}}\right)$ & $\mathbf{E m} \boldsymbol{\lambda}_{\max }(\mathbf{n m})$ & Stokes shift $(\mathbf{n m})$ & $\Phi^{\boldsymbol{a}}$ \\
$\mathbf{1}$ & 560 & 56900 & 568 & 8 & 0.98 \\
$\mathbf{3 a}$ & 654 & 57700 & & & \\
$\mathbf{3 b}$ & 562 & 22800 & 581 & 19 & 0.92 \\
$\mathbf{3 c}$ & 570 & 62800 & 580 & 10 & 0.93 \\
$\mathbf{4 a}$ & 690 & 47000 & & & \\
$\mathbf{4 d}$ & 629 & 72600 & 635 & 6 & 0.21 \\
$\mathbf{4 e}$ & 610 & 64200 & 621 & 11 & 0.37 \\
$\mathbf{5 d}$ & 646 & 73800 & 654 & 8 & 0.27 \\
$\mathbf{6}$ & 517,602 & 20300,20800 & 606 & 4 & $<0.01$ \\
$\mathbf{7}$ & 590 & 68200 & 602 & 12 & 0.98 \\
$\mathbf{8}$ & 589 & 75700 & 615 & 26 & 0.99 \\
$\mathbf{9}$ & 669 & 71300 & 694 & 25 & 0.10 \\
\hline
\end{tabular}

${ }^{a}$ Fluorescence quantum yields were calculated using rhodamine $6 \mathrm{G}$ or methylene blue ( 0.80 and 0.03 in methanol, respectively) as references with a Fluorolog-3 Modular spectrofluorometer. 